\title{
The Topography of Honours
}

Delphi differed from other Panhellenic sanctuaries, since, unlike Olympia, Nemea and Isthmia, it lay in direct contact with a permanent settlement which possessed its own political institutions. The temenos of Delphi served as a public space in which the religious and festive sphere merged and mingled with the political realm and the city's daily life. ${ }^{1}$ The location of the bouleuterion and prytaneion within the peribolos implies that many aspects of Delphic civic life took place there, ${ }^{2}$ while stoai (being commonly situated in other Greek cities within the agora) served as commercial spaces, law courts, philosophy schools and magisterial offices. ${ }^{3}$ As a result, the Delphic temenos was a politically charged space within which citizens and guests could establish and foster both civic and international relationships.

Such relationships directly reflect the connection between power and space, which is my main point of interest in this chapter. The last decades have seen considerable interest in understanding how Greek public spaces and societies interact with, shape and influence one another. ${ }^{4}$ O.M. van Nijf and a group of his former students have re-interpreted Greek public spaces by focusing on their architectural developments, the civic identity that was expressed through the built environment, and social interactions that took place on public soil in the Hellenistic and Roman periods. ${ }^{5}$ They draw on the so-called 'spatial turn' in order to demonstrate how public space is important not only for understanding buildings but also for understanding people. Space and society co-existed with each other, each shaping and in turn being shaped by the other. To fully understand human society, it is thus necessary to think about the relationship

1 For differences between sacred and public space in Greece, see Rousset 2013, 113-133.

2 Jacquemin 1999, 33-35. The exact relation between the Delphic sanctuary and its city-state remains difficult to determine, since Delphi was indiscriminately called a polis in both the urban (Hdt. 8.36.2; Ps.-Scyl. 37) and the political sense (CID 1.9A 2-3.) Cf. Rousset 2002; Oulhen 2004, 412; Ma 2013, 67-75 and 111-150. For problems with applying appropriate terminology, see Jacquemin 1999, 24-25.

3 Dickenson 2013, 6o-63 and 2017, 99-112.

4 Those who raised the question of the control of space through erecting honorific statues include e.g. Griesbach 2010, 3-11; Dillon and Baltes 2013, 207-246 and Herbin 2014b, 161-181. For conflicts in Greece reflected in tensions in the use of the public space, see Dickenson 2017 b, 21-38.

5 van Nijf 2011; Dickenson and van Nijf 2013; Williamson 2014a, 2014b, 2016; Zuiderhoek 2014 and 2017; Heller and van Nijf 2017b; Dickenson 2017a. 
between society and the space it inhabits. A space only becomes public once it is filled with people and activities associated with the public realm.

A fascinating case-study, the Delphic urban space, reflects political interactions at both the local (e.g. between Delphi and the Amphictyony, or between the Delphic elites and the non-elite citizenry) and the international level (e.g. between Delphi and the Aetolian League). This chapter discusses these relations by examining the locations of honorary statues and honorific decrees within Delphic public space, which enabled aspects of spatial domination and the control of space at Delphi to be examined. One of my main concerns is therefore to bring epigraphic material to the forefront of research in understanding the relationship between space and society.

This chapter is divided into three sections. The first section explores the physical context of decrees displayed at Delphi, i.e. the types of media on which the decrees were inscribed and the places where they were displayed. This is followed by an examination of the types of media which is typically employed by foreigners at Delphi and the Amphictyonic League, compared with the publishing habits of Delphi's citizens. The second section devotes itself to examining honorific statues located within the Delphic temenos, with a particular focus on issues concerning the 'monumentalisation' of Delphi, and reveals how the process of prestige spatialisation (via the erection of honorific portraits) worked. The third and final section discusses certain aspects of the connection between power and space.

At this point, I must reemphasise that, in many respects, the Delphic honorific habit stood out among other poleis, especially in relation to Athens and Olympia. From the early sixth century вСе to the end of antiquity, the Delphic temenos hosted almost the entirety of Delphi's epigraphic output (Map 10). Apart from the Marmaria (the sacred area with the temple of Athena Pronaia) where several statues of the Roman emperors were found, ${ }^{6}$ it was the small holy precinct in which the mighty dedications of archaic and classical periods stood, all manumission records along with thousands of honorific decrees were erected, and honorary portraits were located. In contrast, the Athenian epigraphic output was spread out over large territories of the Athenian agora and Akropolis. By the end of the fifth century BCE, the Akropolis accumulated the bulk of Athenian epigraphic production, whereas from the $420 \mathrm{OSCE}$ onwards the Athenians tended to place honorific monuments and decrees in

6 According to Pausanias, an unspecified Marmarian temple housed statues of Roman emperors (Paus. 10.8.6.). Indeed, a portrait of Hadrian dedicated by a Delphic priest was found in Marmaria, in front of the Doric treasury $\left(\right.$ Syll $\left.{ }^{3} 835^{B}\right)$. See Choix 2012, no. 254. 
their agora. Additionally, according to Liddel, 6,5\% of Athenian decrees were set up in Athens in locations other than the agora and Akropolis. ${ }^{7}$

The uniqueness of Delphi's space for epigraphic display also relates to geographical surroundings. Built onto a steep hillside, the sanctuary of Apollo in Delphi was built upon several strategically erected terraces; due to spatial constraints, buildings in the Delphic holy district were built closer to one another than was customary, were often overshadowed by neighbouring constructions, and were smaller than, for instance, those in Olympia. All this greatly impacted the local honorific habit. ${ }^{8}$ The hunger for space eventually also encouraged the arrangement of new monuments which exerted a lasting visual impact on viewers. Hence, the analysis of Delphic honorific documents in their milieu allows us to 'read' the space not only through legible inscriptions, but also through the carefully arranged placement through which they shaped the local topography.

\subsection{The Landscape of Epigraphy - the Location of Delphic Decrees}

The aim of this section is to follow Peter Liddel's 2003 work on the placement of published Athenian state decrees and to use it to shed light on the casestudy of Delphi. ${ }^{9}$ Liddel investigated c. 1679 Athenian state decrees, reaching the conclusion that only $553(33 \%)$ of them include a publication clause which refers to the initial setting of the inscriptions. ${ }^{10}$ This is due to the fact that Athenian decrees were displayed on free-standing stelai within the Akropolis, the agora, the Asklepieion and other minor sanctuaries. Without the preserved

$7 \quad$ Liddel 2003, 79-93; Shear 2007, 91-115.

8 Scott 2010, 223 .

9 So far, the scholarly community has produced few in-depth studies on the significance of placement in ancient Greek honorific decrees within the public space. On the location of the Athenian decrees, see especially Liddel 2003, 79-93 and references in fn. 3 and 4 in his article; Meyer 2003, 453-505; Shear 2007, 91-115; and the project of Lasagni's team 'The epigraphic landscape of Athens'. For the location of the Oropians' proxeny decrees, see Wilding 2015, 55-81; for the decrees from Megara, see Liddel 2009, 411-436. Weir (2004, 91-92) discusses some Delphic decrees inscribed upon the Delphic treasuries. Sears, Keegan and Laurence's recent publication (2015) collects essays on the practice of writing in the Roman public space, with the following contributions being of particular interest to this study: Corbier's chapter on writing within the Roman public space (13-47); Newsome's chapter on the movement and rhythms evidenced in the written space (65-81); Trifilò on writing space in Platea (179-183); and, finally, Cleary and Revell's chapters on writing in public spaces of Aquitania (Cleary 217-230) and Roman Baetica (Revell 231-245). 
clause concerning the primary emplacement of the stela, the knowledge of its site is often lost. In Delphi, the vagaries of the local epigraphic habit ensured that many locations would remain known, with $79,5 \%$ (6o4) of surviving state decrees inscribed on building walls and only $20,5 \%$ (156) on free-standing stelai. ${ }^{11}$ The locations of eight out of 156 stelai come down to us through either the decree's text or the actual finding spot. ${ }^{12}$ By providing this wealth of epigraphic evidence, Delphi's decrees outnumber Athenian decrees examined by Liddel.

\subsubsection{The Types of Media Used at Delphi}

Before attempting to elaborate the places of published Delphic decrees, it will be useful to discuss briefly the types of media on which the Delphic decrees were displayed. The data is categorised by century up to the advent of the imperial period, which has its own category due to the fact that a large proportion of abbreviated decrees issued between the first and third centuries CE are dated generally as 'imperial' texts.

Out of the 760 decrees, 156 were inscribed on stelai and the remaining 604 on surfaces of monuments located within the Delphic temenos, with building walls serving as the preferred medium upon which the Delphians carved their decrees. The tabulated data allows for several other observations. First, the Delphians produced the largest number of stelai in the fourth century BСE, when their decree habit was in its initial phase. ${ }^{13}$ Moreover, the evidence available for the fourth century reveals that grants of honours dated to this century were more often inscribed upon free-standing stelai than upon building walls. From the beginning of the third century BCE in Delphi, this trend reversed; the surfaces of treasuries, polygonal wall and large statue bases replaced stelai as the preferred media for honour grant inscriptions. I have already explained at length in Chapter 5 why the Delphians turned to inscribing honours on

11 Inscriptions that do not indicate or preserve the place of publication have not been included. Delphic decrees have been systematically published in six fascicules of Fouilles de Delphes. In Tome III: Épigraphie (FdD), the editors discussed the physical medium of stone and its spatial context. Regrettably, certain Delphic documents (published in the late 19th century Sammlung der griechischen Dialekten-Inschriften) for one reason or another lack information regarding the location of the stones (for instance, SGDI 266o). For a large group of decrees published in the first fascicule of $F d D$, locations cannot be precisely determined, and all that is known about them is that these decrees probably came from the lower part of the sanctuary (Delphic decrees: FdD 1.391-471; Amphictyonic documents: $F d D$ 1.472-480; decrees of others poleis: $F d D$ 1.481-485).

12 Syll $l^{3}$ 21B; $F d D$ 3.216, $F d D$ 3.219, $F d D$ 3.222, FdD 3.224, FdD 3.228, FdD 3.379-38o.

13 See Chapter 1. 


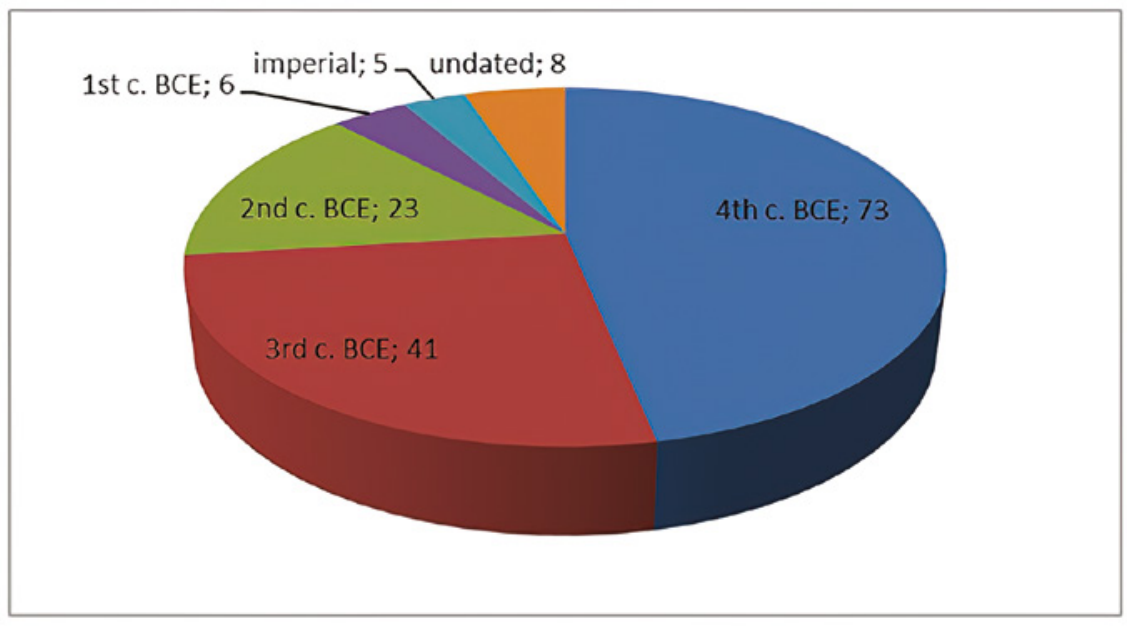

FIGURE 12 The number of Delphic decrees displayed on stelai (156 in total)

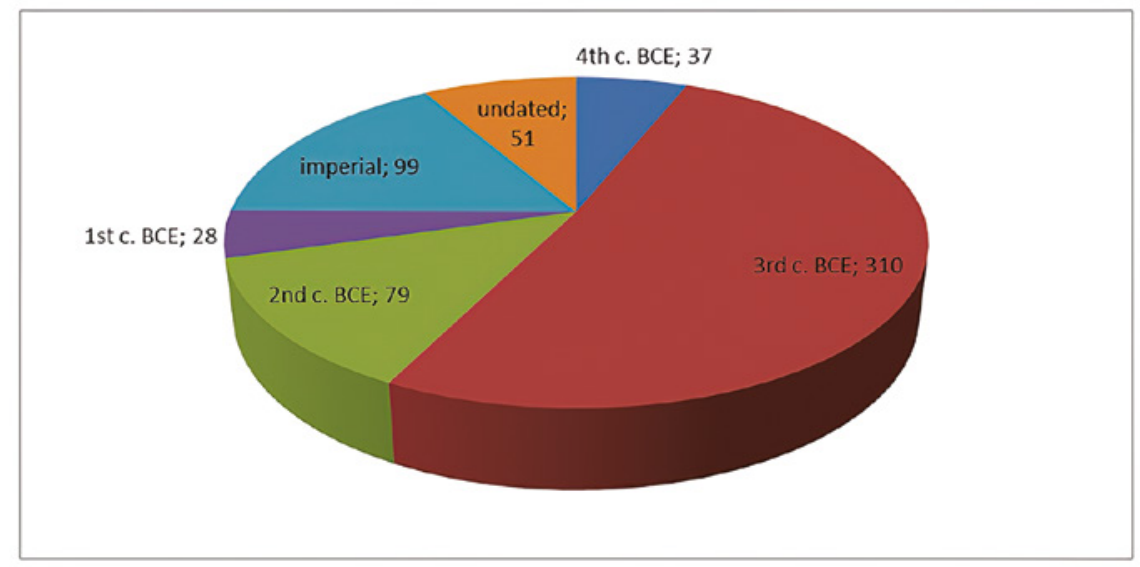

FIGURE 13 The number of Delphic decrees displayed on building walls (6o4 in total)

building walls, so I will recapitulate my points briefly below. ${ }^{14}$ (1) Writing a decree on a wall offered greater durability to enactments. (2) It avoided epigraphic congestion in the Delphic temenos, as engraving statue bases and massive square pillars (with two or four sides) optimised space and material usage. (3) Inscribing abbreviated forms of decrees on buildings and statuary surfaces incurred fewer costs than inscribing full pattern decrees on free-standing stelai. By the time the Delphic decree culture reached its peak, the citizens of

14 Chapter 5.1.1. 
Delphi adopted building walls as their main epigraphic medium (Chapter 1, Figure 1). This development was spurred on by a sharp rise in the number of voted decrees, with the honorific output of the third century вСе being more than three times the total of the fourth century output.

The data contained within Figures 12 and 13 point to yet another remarkable development - an apparent upsurge in the number of decrees inscribed on the building walls and dated to the imperial period, numbering 99 decrees in total. From the last quarter of the third century вСЕ onwards, the Delphic polis inscribed fewer and fewer texts on walls and stelai. The ostensible reversion of this trend in the imperial era stems partly from my decision to enter all decrees granted between $1-25 \mathrm{O}$ CE together into a single category, in contrast to earlier decrees, which were categorised century by century. In fact, Delphi in the imperial period saw only a brief renaissance in its honorific culture, the number of granted decrees rising in the second century $\mathrm{CE}$, especially under Hadrian's reign (Chapter 1, Figure 1). This brief window of time witnessed the increased epigraphic output of statues, decrees and grants of honours to a broader range of personages in Delphi and abroad. ${ }^{15}$

\subsubsection{The Locations of Delphic Decrees}

As mentioned above, we know of only eight exact Delphic stelai locations out of 156 preserved pieces in total. ${ }^{16}$ One of these texts (dated to a period between 81-96 CE, which concerns Delphi's answer to a letter from Domitian) contains

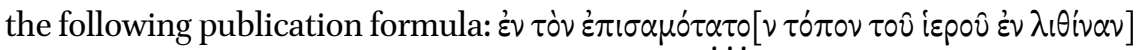
$\sigma \tau \alpha^{\prime} \lambda \alpha \nu \dot{\varepsilon} \nu \chi \alpha \rho \alpha^{\prime} \xi \alpha \mathrm{l} /$ 'to engrave on a marble stela, in the most eminent place in the sanctuary' (1. 3-4). ${ }^{17}$ The remaining seven stelai with known original locations date to the third century вСЕ. Five of these, which confer honours upon the citizens of Chios, were raised by the Delphians next to the Chian altar, ${ }^{18}$

15 For honorific statues erected at Delphi in the second century вСЕ, see Grzesik 2019, 214-216.

16 Pouilloux (1976) published 111 Delphic proxeny decrees inscribed on stelai or marble blocks that were not fragments of building walls. They all come from the region between the temple and the northern precinct area; their primary settings are, however, unknown. See $F d D$ 4.373-450.

17 Syll $821 \mathrm{~B}$; Choix 2012, nos. 230-233.

$18 F d D_{3.216}, F d D_{3.219}, F d D_{3.222}, F d D_{3.224}, F d D_{3.228}$. No. 224 bears the publication clause:

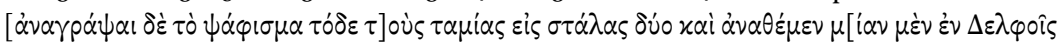

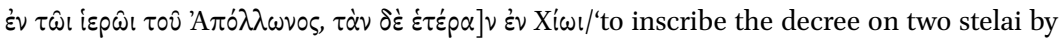
the officials and place one in Delphi in the sanctuary of Apollo and the other one in Chios' (l. 14-15). 
whereas two stelai, which record honours granted to private individuals from Rhodes, originally adjoined the area that housed the offering of the Rhodians. ${ }^{19}$

The data compiled in the next table (Table 7), which presents the locations of Delphic decrees engraved on building walls, contain a series of interesting patterns. Nearly one third of all decrees appeared on just three monuments: the Treasury of the Siphnians, the polygonal wall and the Treasury of the Athenians. The most heavily engraved monument, the Treasury of the Siphnians (dated to the sixth century BCE), bears texts of over a tenth of all Delphic state decrees. Its visibility contributed to its popularity for engravers: decree texts predominantly marked the Treasury's eastern and northern flanks, whose conspicuous walls were visible to pilgrims passing along the Sacred Way. ${ }^{20}$ In contrast to other treasuries in Delphi, inscriptions on the Treasury of the Siphnians date most of all to the imperial period. Surprisingly, no honour awarded to any citizen of Siphnos appears on the walls of their Treasury, even though it was a common practice at Delphi to inscribe decrees for the citizens of particular poleis onto the walls of monuments which were dedicated by those cities. Pertinently, the available evidence indicates that ties between Delphi and Siphnos weakened after the erection of the Treasury, with the Siphnians losing interest in maintaining their monument. ${ }^{21}$ For centuries, the walls of the Siphnian Treasury remained untouched, with the earliest decrees discovered on its walls postdating $15 \mathrm{O} \mathrm{BCE} ;^{22}$ only in the imperial period did the walls of the Treasury become a popular space for the city's epigraphic output. ${ }^{23}$

The polygonal wall ranks second in Table 7, with 62 Delphic state decrees. This large and remarkable sixth century вСе construction supports the platform upon which the temple of Apollo stands. ${ }^{24}$ Throughout the centuries, it served as a surface for inscribing texts of state decrees, Amphictyonic documents and manumission records. ${ }^{25}$

The majority of the recipients of Delphic honours recorded upon the Treasury of the Athenians were in fact citizens of Athens, indicating an ongoing and strong relationship between Athens and Delphi. ${ }^{26}$ The Delphians honoured the Athenians more frequently than the Athenians did the Delphians: Delphians became proxenoi of Athens only twice, in the late fifth and early

\footnotetext{
$19 \quad F d D 3.379$ and 38 o.

20 Partida 2000, 35-47; Weir 2004, 9 o.

21 Paus. 10.11.2.

22 The earliest example: $F d D$ 1.26o (146 в $\mathrm{E}$ ) for a citizen of Hypata.

23 At least forty texts number from this period.

24 Paus. 10.16.7; Guide 2015, 199-216.

25 Choix 2012, nos. 234-235.

26 FdD 2.71-134; Syll 395 and 704C. See Bankel 1990, 410-412; Partida 200o, 48-70; Neer 2004, 63-93.
} 
TABLE 7 Specific locations of Delphic decrees displayed on building walls

Monument

Treasury of the Siphnians

Polygonal wall

Treasury of the Athenians

Base of the kings of Argos and the niche next to it

Base of the Boeotians

Base of the Arkadians

Cippi near the Treasury of the Athenians

Monument of the Messenians

Monument of Aemilius Paullus

Pillar of Eumenes II

Treasury of the Knidians

Treasury of the Kyrenians

Base of the Aetolians

Treasury of the Thebans

Monument of Prusias II

Treasury of the Syracusans

Theatre

Other monuments

Total
Total number of decrees

$64(10,5 \%)$
$62(10 \%)$
$49(8 \%)$
42
39
35
32
30
24
22
17
15
13
10
9
2
1
138
604

fourth centuries BCE, whereas Delphi made Athenians its proxenoi at least 62 times, and most of these honours were recorded on the Treasury walls. ${ }^{27}$ The material sample indicates that the Delphians preferred to honour citizens of foreign poleis on the walls of their respective treasuries and monuments, with the inscriptions placed in contexts most relevant to their content. Such was the arrangement at the treasuries of the Knidians, ${ }^{28}$ Kyrenians $^{29}$ and Thebans, ${ }^{30}$ or on the bases of the Arkadians ${ }^{31}$ and the Boeotians. ${ }^{32}$ If a foreign polis had an offering or a monument in Delphi with a surface free for inscriptions and if contacts between the city and Delphi remained strong, then, in the Hellenistic period, one could expect that the said building or monument

$27 I G \mathrm{I}^{3} 27$ and $I G \mathrm{II}^{2} 51$. See Chapter 3.

$28 \quad F d D$ 1.290, $F d D$ 1.196, $F d D$ 1.299-301, $F d D$ 1.3०8, $F d D$ 1.314, $F d D$ 1.327.

$29 \quad F d D$ 3.163, $F d D$ 3.165-166, $F d D$ 3.169. Partida 2000, 147-172.

3о $F d D$ 1.354-365.

$31 \quad F d D$ 1.12-46 (with some unknown ethnics).

$3^{2} \quad F d D$ 3.78-116 (with some unknown ethnics). 
would display honours granted to that polis' citizens. ${ }^{33}$ This publication habit also applies, although less forcefully, to Romans honoured at Delphi; for example, the Delphians engraved the pillar of Aemilius Paullus with five decrees for Roman citizens. ${ }^{34}$ At Hellenistic-era Delphi (and perhaps even into the imperial period) the authorities took care to place new decrees in appropriate epigraphic contexts that would align with their contents; for example, a musician from Magnesia on the Meander received an inscription dated to a period between $2 \mathrm{O}-75 \mathrm{CE}$ engraved on a statue base belonging to another artist, the placement being guided by their professional association. ${ }^{35} \mathrm{~A}$ similar example comes from first-century CE Kos, where an honorific inscription for an unknown poetess, a joint citizen of Alexandria and Kos, was inscribed upon the statue base of another poetess. ${ }^{36}$

The decree honouring the musician from Magnesia on the Meander sheds some light on attitudes toward communities who did not possess a monument in Delphi which was to be used to display honours voted for their citizens. The bulk of decrees granted to inhabitants of peripheral areas, such as Karia, Kilikia, or Italian cities, came from the cippi near the Treasury of the Athenians, ${ }^{37}$ from exedras and niches located along the Sacred Way, or from the polygonal wall. ${ }^{38}$ Many of the surfaces on which new decrees were superimposed were originally granted to other communities, the reasoning behind these placements often remaining a mystery. ${ }^{39}$ Perhaps the Delphians saw some obscure links, in subject matter or in political relations, between the newer honorands of superimposed inscriptions and the older honorands of surfaces on which these inscriptions were placed. Regrettably, most of these inscriptions come in abbreviated form, yielding little information on the honorands and any connections they may have had to the owners of the monument on which their inscriptions were engraved.

One notable monument superscribed with honorific decrees, the pillar of Eumenes II, reveals a wealth of intriguing details about the practice. On this

33 There are, however, exceptions to this rule. The monument of the Messenians bore inscriptions granted to both the Messenians (eleven grants) and private individuals from other foreign cities (nine attestations). See $F d D$ 4.4-34.

$34 F d D$ 4.44-48. For the monument of Aemilius Paullus, see Kähler 1965; Jacquemin and Laroche 1982, 191-218; Boschung 2001, 59-72; Taylor 2016, 559-576.

$35 \quad F d D_{3.129 .}$

$36 \quad I G$ XII,4 2, 845. See, Bosnakis 2004, 99-108.

$37 \quad F d D$ 2.176-178, FdD 2.180-181.

$38 \quad F d D$ 2.208. Tarentum set up their own monument in Delphi (500-475 вCE), which was later covered with decrees for citizens of Tarentum ( $F d D$ 1.131 and $F d D$ 1.135).

39 E.g. the decrees for citizens of Mallos (Kilikia, $F d D$ 1.84) or Sinope ( $F d D$ 1.85), which were engraved upon the statue base of the kings of Argos. 
Aetolian dedication of 196 все, the original dedication and the superscribed decrees co-existed harmoniously, as can be clearly perceived from their visual arrangement. ${ }^{40}$ The original dedication for Eumenes II, which was positioned on the east side of the monument, faced the Sacred Way; its wall remained bare for over 250 years, as all surrounding superscribed decrees postdate $8 \mathrm{O}-95 \mathrm{CE} .{ }^{41}$ On the less prominent south-facing wall, the citizens of Delphi and the Aetolians began to engrave decrees at some point between 196-166 вСЕ, first employing the smallest scripts possible; all of the new decrees during this time concern either Eumenes II or the envoys which he sent to Delphi. ${ }^{42}$ In turn, the north- and west-facing walls of the monument eventually bore decrees which granted honours to citizens of unrelated poleis. Two of these inscriptions, which were granted in 86 вСЕ to Polygnota, a harpist from Thebes, and to her cousin, illustrate additional prestige conferred by having one's decree superscribed upon an older, more famous construction. ${ }^{43}$ Polygnota came to Delphi to participate in the Pythian Games; still, the ongoing war between Sulla and Mithridates prevented the festival from taking place. Not being discouraged, the Theban harpist performed independently in Delphi and received much praise for her music: she received a monetary reward and numerous Delphic privileges, including proxenia, promanteia (priority to consult an oracle), proedria (privilege of front-row seats), prodikia (priority of trial), asylia (immunity from the right of reprisal), and ateleia (exemption from public burdens). ${ }^{44}$ Superscribing her honorific decree on the pillar of Eumenes II provided yet another privilege, as, by virtue of its spatial contiguity, the prestige of illustrious primary dedications radiated outwards and added to the prestige of the secondary inscriptions clustered around them. In light of these considerations, it appears that superscribing decrees were not supposed to surpass or take away from the primary inscription. On the contrary, the textual arrangement on the walls of the pillar of Eumenes II shows how later decrees carefully supplemented the main text, drawing from its prestige and in turn adding to it.

A similar tendency is attested on the grand base of the Rhodian Chariot, where the main dedication of the early third century BCE is located on the northern flank of the monument (on top) and is accompanied by twelve later manumission records inscribed with much smaller scripts (Figure 14).45

\footnotetext{
$40 \quad F d D$ 3.23o. See Daux 1943a, 201-203.

$41 F d D 3.231$ (first century CE), 3.232 (98/9 CE), 3.233 (8O-95 CE), 3.234 (first/second century $\mathrm{CE}$ ), 3.235 (first/second century CE), 3.236 (first/second century CE).

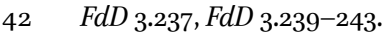

$43 \quad F d D$ 3.249-250.

44 Bélis 1999, 53-55; Chaniotis 2009, 87-91; Choix 2012, nos. 208-209; Perrot 2013, 205-206.

$45 \quad F d D 3.378$ and $3.385-3.396$.
} 


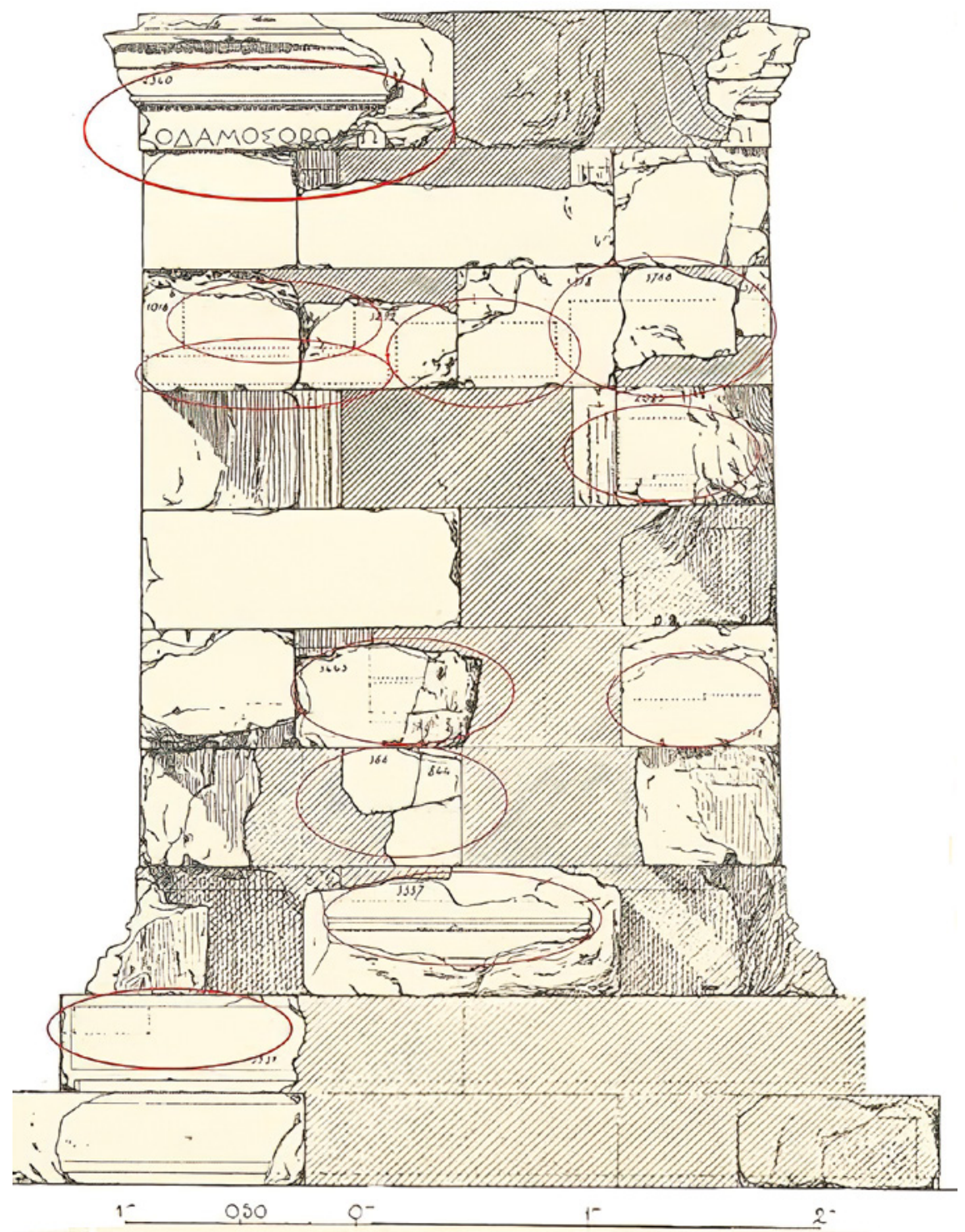

FIGURE 14 Reconstruction of the base of the Rhodian Chariot (northern flank) and the display of the main dedication (on top) and later manumission records Note: Reconstruction after Daux 1943a, 338, fig. 28 with modifications and adjustments made by the author. 


\subsubsection{The Decrees of the Amphictyony and Other Communities at Delphi}

My analysis so far has centred on the systemic placement of the honorific decrees in Delphi. In this section, I will address the preferred epigraphic loci for foreigners and the Amphictyonic League which were published in Delphi, with my aim being to appraise how the domestic publishing habit paralleled and departed from the practices of foreign communities attested at Delphi. Before proceeding, we should consider how a foreign community or foreign private individual selected or suggested a location for a decree or statue they set up in Delphi. Regrettably, the preserved material does not yield any definitive answers. It is unlikely that the foreigners decided where their honorific monuments/decrees should be placed within the temenos without the explicit permission from either the Delphic assembly or the Amphictyony. Most likely, the Delphians either recommended a location or they agreed on a location recommended by either the recipient of the awarded honour or the proposer of the motion. ${ }^{46}$

In the case of the Aetolian decrees and monuments displayed within the Delphic public land, the city might have had less say in their emplacement. As I will demonstrate in the following paragraphs, the honorific and publishing habits of the Aetolian League at Delphi differed from those of other foreign agents. The League controlled Delphic officials, the Delphic territory, and the Amphictyonic council; therefore, the Aetolians during the period of their domination over the Delphic sanctuary might have held a special dispensation to shape the sanctuary's space, including having a free reign over selecting locations for new honorific structures. The surviving monuments imply that the Aetolians controlled their exclusive sector in the sanctuary, but it is not known whether their power spilled over into any other areas in the sacred precinct.

The League of the Amphictyony produced $c .110$ decrees, which come down to us in the form of stone inscriptions. ${ }^{47}$ The numbers of texts engraved on stelai and on building walls almost match (with a ratio of 49 to 51 ), in contrast to the domestic publishing culture at Delphi which predominantly used surfaces of buildings as its publishing medium (with a ratio of 79,5 to 20,5 ). Significantly, the domestic epigraphic output in Delphi exceeded the epigraphic output of the Amphictyony in Delphi by at least ten times: even accounting for the

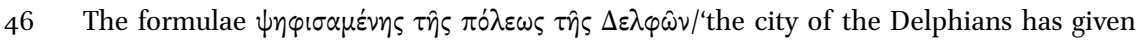
its approval by decree' ( $F d D$ 3.67-70), $\psi(\eta \varphi$ i $\sigma \mu \alpha \tau \iota) \beta(\circ \nu \lambda \hat{\eta} \varsigma) /$ 'by decree of the boule' ( $F d D$

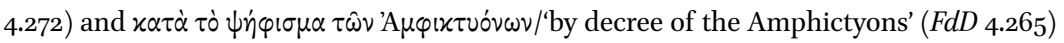
(attested in many variations) reflect the fact that the polis or the Amphictyonic council have voted to grant the right to display a statue in the Delphic public space. These phrases, however, survive only in the tituli honorarii from the imperial period (see Jacquemin 1999, 109).

Most of these decrees appear in CID 4 . 
Delphian disinclination to publish on stelai, the Delphians still raised more decrees on stelai (156) than the Amphictyony (51). By publishing fewer decrees, the Amphictyony could alternate between stelai and building walls as honorific media, thus avoiding overcrowding the temenos, particularly in the critical third century ВСЕ.

The League of the Amphictyony engraved its decrees on the same buildings as the Delphians; the polygonal wall was the find-spot of the bulk of Amphictyonic documents, ${ }^{48}$ while several were found on treasuries belonging to the Athenians ${ }^{49}$ Knidians, ${ }^{50}$ Thebans ${ }^{51}$ as well as on the hemicycle of the kings of Argos. ${ }^{52}$ Yet it is the publication habit of the Aetolians that stands out and deserves our closer attention. Although it was never a legal administrator of the Delphic territory, the League of the Aetolians repelled the Gallic invasion of Delphi in 279 вСE and subsequently became the dominant power within the Amphictyony, gaining the votes and influence which were once held by other central Greek poleis but then who were conquered and diminished by the Aetolians. Wielding their new-found power, the Aetolians reorganised the Soteria festival in Delphi, entrusting its organisation to the Aetolian agonothetai, and assumed responsibility over the epimeletai of the sanctuary. ${ }^{53}$ But gaining control over Delphi's main festivals, officials and the Amphictyonic council was just the first step in what would become the Aetolian subjugation of the Delphic territory. ${ }^{54}$

The unprecedented rise of the Aetolian power at Delphi parallels certain developments in the Aetolian honorific habit there. As Table 8 indicates, out of 18 foreign-granted decrees (whose primary spatial setting is known) located within the territory of Delphi, seven were voted by the League of the Aetolians between $259-183 / 2$ BCE, and so during the period of their domination over Delphi.

48 CID 4.23, CID 4.43-44, CID 4.58-6o; Syll $3444 \mathrm{~A}-\mathrm{E}$.

$49 \quad$ CID 4.127 and CID 4.134 .

5 O CID 4.26.

$51 \quad$ CID $4.70-72$.

52 CID 4.14-15.

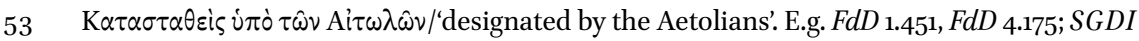
2672. See Sifakis 1967, 64; Sánchez 2001, 306-309.

54 See below, and cf. Scholten 200o, 30-95. 
TABLE 8 The location of decrees of foreign communities at Delphi

\begin{tabular}{|c|c|c|c|c|}
\hline No. & Granting authority & Date & Location & Attestation \\
\hline 1. & Aetolian League & $259-255$ ВСЕ & exedra near the aire & $F d D 3.144$ \\
\hline 2. & Aetolian League & 225 BCE & polygonal wall & Syll 479 \\
\hline \multirow[t]{2}{*}{3.} & Aetolian League & early 2 nd century & Treasury of the & $F d D 1.535$ \\
\hline & & BCE & Thebans & \\
\hline \multirow[t]{2}{*}{4.} & Aetolian League & early 2 nd century & Treasury of the & $F d D 2.90$ \\
\hline & & ВСE & Athenians & \\
\hline \multirow[t]{2}{*}{5.} & Aetolian League & $205 / 4-203 / 2$ ВСЕ & Treasury of the & $F d D$ 2.134a \\
\hline & & & Athenians & \\
\hline \multirow[t]{2}{*}{6.} & Aetolian League & 194-171 ВСЕ & on the wall in the & $\mathrm{BCH}$ \\
\hline & & & sanctuary & $5.1881 .404,14$ \\
\hline $7 \cdot$ & Aetolian League & $183 / 2$ ВСЕ & pillar of Eumenes & $F d D_{3.240}$ \\
\hline 8. & Tegea & $324 \mathrm{BCE}$ & stela & Syll 306 \\
\hline 9. & Erythrai in Ionia & 26o BCE & stela & $S y l l^{3} 412$ \\
\hline 10. & Erythrai in Ionia & 26о ВСЕ & stela & Syll 413 \\
\hline 11. & Chios & 247 BCE & stela & $F d D 3.214$ \\
\hline 12. & Chios & 246 вСЕ & stela & $F d D 3.215$ \\
\hline 13. & Chaleion & $218 / 217$ ВСЕ & exedra near the aire & $F d D_{3.145}$ \\
\hline \multirow[t]{2}{*}{14.} & Lilaia & 208 вСЕ & monument of the & $F d D 4.132$ \\
\hline & & & Lilaians (?) & \\
\hline \multirow[t]{2}{*}{15} & Lilaia & 208 вСЕ & monument of the & $F d D 4.133$ \\
\hline & & & Lilaians (?) & \\
\hline \multirow[t]{2}{*}{16.} & Lilaia & 208 вСЕ & monument of the & $F d D 4.134$ \\
\hline & & & Lilaians (?) & \\
\hline \multirow[t]{2}{*}{17.} & Lilaia & 208 вСЕ & monument of the & $F d D 4.135$ \\
\hline & & & Lilaians (?) & \\
\hline \multirow[t]{2}{*}{18.} & Daulis in Phokis & $9 \mathrm{O}-85$ ВСЕ & monument of & $F d D 4.59$ \\
\hline & & & & \\
\hline
\end{tabular}

All seven Aetolian decrees are inscribed on the surfaces of buildings which were initially used by the Delphians and the Amphictyons to display their honorary documents. Other poleis whose honorific activity is attested at Delphi selected stelai (five examples) or their own monuments at Delphi to publish their decrees (four examples). For example, the citizens of Daulis and Chaleion engraved decrees on the base of Aemilius Paullus and on the exedra near the 
aire, most probably because they had no monuments in Delphi onto which to superscribe their decrees. The publication habit of the Aetolians at Delphi reveals another aspect of the Aetolian domination over Delphic land; to express its power, the League adopted the Delphic publishing style and eternalised its decrees on Delphic monuments instead of using their own constructions. In contrast, the Aetolians at Thermon placed their decrees almost exclusively on free-standing stelai, following the local custom. ${ }^{55}$

The overcrowding of the Delphic temenos, availability of appropriate monumental building surfaces, and rising costs of honorific production all sufficiently explain the Delphic inclination to publish decrees on building walls. The foregoing examination demonstrates that the Delphians, the Amphictyons and (to some extent) the Aetolians exploited the available material to the maximum. In the Roman period, the walls of the previously empty wall of the Treasury of the Siphnians were covered with inscriptions, as was the prominent east side of the pillar of Eumenes II. Honorific texts informed literate passers-by about honorands, their benefactions for the city and their relations with the granting authorities. Together with the honorific portraits, decrees were a form of self-presentation and thus a very important component of the entire honorific culture, although their visibility has often been neglected by scholars. Stone inscriptions gave honours a physical form, and thereby the power to impact upon the visitors' perception, local topography and the arrangement of public space.

\subsection{The Monumentalisation of Delphi - the Honorific Statuescape of Delphi}

The survey of Delphic decrees and inscriptions accompanying statues aims, inter alia, to illuminate connections between power, space and collective memory in the Delphic temenos. In this section, I argue that, similarly to carefully selected locations of decrees, honorific statues within the Delphic temenos occupied methodically arranged sites, and that their choice was influenced by the availability of space, the visual prominence (absolute and relative) of the monument to be erected, the prestige of neighbouring constructions and the expected number of visitors in the target area. ${ }^{56}$ Far from being static, every statuary culture evolved in response to political, social and spatial stimuli. On this picture I will recast the statuary culture at Delphi as an

$55 I G$ IX,1 $1^{2} 1-5$ O.

$5^{6}$ Grzesik 2018a, 23-42. 
expanding network of nodes set in time and space, as new monuments abutted or overshadowed older ones and inscriptions wound their way into previously unmarked spaces. ${ }^{57}$ As a result, we will move across the temenos in time and space to discuss how the evolving honorific/statuary habit in Delphi rearranged the sanctuary space, creating confluxes of prestige. ${ }^{58}$

Evidence regarding the visibility of specific honorific monuments in the Delphic temenos primarily come from eyewitness accounts in Plutarch and Pausanias and surviving archaeological/epigraphical material, providing evidence for approximately 281 portraiture pieces from Delphi. Other poleis have yielded varying amounts of material concerning the visual prominence of specific monuments. The Athenian dataset encompasses 800 honorific inscriptions from the imperial period. ${ }^{59}$ In Olympia, as narrated by Plutarch, over 1000 statues embellished the local sanctuary, including 274 portraits of victorious athletes and other votive offerings and honorific statues granted by citizens of Greek poleis and federations. ${ }^{60}$ The city of Aphrodisias yielded 274 items (ranging from the first century BCE to the early third century CE), ${ }^{61}$ whereas Dodona, another oracular sanctuary in mainland Greece, produced 62 surviving statue bases and over 100 bronze pieces from the statues, but only four inscriptions. ${ }^{62}$

In comparison to abundant evidence from Olympia and Athens, 281 location-confirmed artefacts from Delphi may seem rather scarce, with an output of 0,4 statue per annum in the 70o-year sample. After being fought over and plundered by numerous factions (including the Phokians and the Gauls), Delphi suffered most when it lost 500 images to Nero, as related by Pausanias. The sheer magnitude of Nero's appropriation showcases how many honorific

$57 \quad$ Richter 1965; Fittschen 1988; Smith 1988; Stewart 1993; Dillon 2006; Schultz and van den Hoff 2007; Ma 2013; Dillon 2010; Dillon and Baltes 2013; Griesbach 2014; Keesling 2017; Stoop 2017, 3-36.

58 For the chronological distribution of honorific statues in Delphi, see Grzesik 2019, 200-227.

59 Camia 2017, 115. For portrait statues in Athenian decrees from the Hellenistic period, see Oliver 2007, 181-204.

6o Krumeich 2017, 214. See also Bol 1978; Herrmann 1988, 119-183; Zoumbaki 20o1. For the votive monuments from Olympia, see Ashmole and Yalouris 1967; Bol 1984; Herrmann 1987.

61 Smith 2006, 5 and catalogue on pp. 77-97.

62 Katsikoudis 2006; See Ma's review: Bryn Mawr Classical Review 2008.02.27. The small number of surviving images from Dodona can be explained through the sanctuary's unique history. After being conquered by the Thracians in 88 все, Dodona was subsequently surpassed in importance by Nikopolis' new sanctuary. In the Roman imperial period, when statue culture flourished in other regions, Dodona had long ceased to function. See Piccinini 2013, 178. 
and votive statues stood at Delphi in the first century $\mathrm{CE}^{63}$ indeed, Pliny reports that even after Nero's plundering Delphi still had over 3,00o statues. ${ }^{64}$ In this instance, Pliny's figure of 3,0oo statues is not meant to be understood literally: rather, the number symbolically refers to the inexhaustible cultural treasure troves of Delphi, Rhodes, Athens and Olympia - to unspecified myriads of statues remaining in the sacred precinct even after Nero's coming. Pliny's exaggerated number, however, makes evident that whatever evidence has survived is only a small fraction of what once existed, and that the scarcity of sources impedes our attempts at drawing unambiguous conclusions. Regrettably, a large number of Delphic statues has not survived to our day. The secondary use of monuments was quite common in all periods at Delphi, from the reinscription of dedications (such as the monument of Aemilius Paullus) to the addition of related or unrelated inscriptions (the pillar of Eumenes II) and the reuse of a monument in the dedication of another monument (the statue base of emperor Carus was reused almost immediately after his death for the monument of Constantinus Chlorus). ${ }^{65}$ Using the evidence available to us, in the following section of this chapter, I will discuss the spatial arrangement of monuments in the Delphic sacred district, beginning from the entrance and then moving towards the temple.

I begin my analysis of Delphi's honorific spaces at the main entrance to the sanctuary, built in the sixth century вСE in the south-eastern section (Map 10, region no. 1). ${ }^{66}$ Although in time seven other entryways were built at each of the terracing levels, the south-eastern entrance remained the principal gate, being accessed annually by thousands of visitors - it thus represented an attractive site for displaying honorific statues and inscriptions. Many poleis attempted to dominate and thus symbolically control this entrance site with their statues and inscriptions. In the late sixth and early fifth centuries BCE, the Athenians congested the entrance space with numerous dedications to highlight their power over Delphi: the offerings encompassed a group statue of Athens' eponymous heroes, a treasury, a stoa, and an image of Miltiades, raised

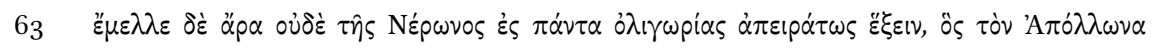

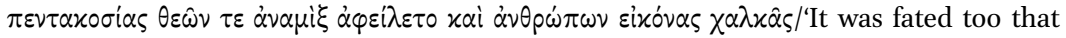
Delphi was to suffer from the universal irreverence of Nero, who robbed Apollo of five hundred bronze statues, some of gods, some of men' (Paus. 10.7.1., trans. Jones and Ormerod). Krumeich 2017, 244-245.

64 Plin. $H N$ 34.36.

65 Jacquemin 1999, 215-232 and no. 153. On re-using statues in Greece, see Shear 2007, 221246; Lenaghan 2016, 267-279; Krumeich 2017, 213-251.

66 Scott 2014, 102-103. 


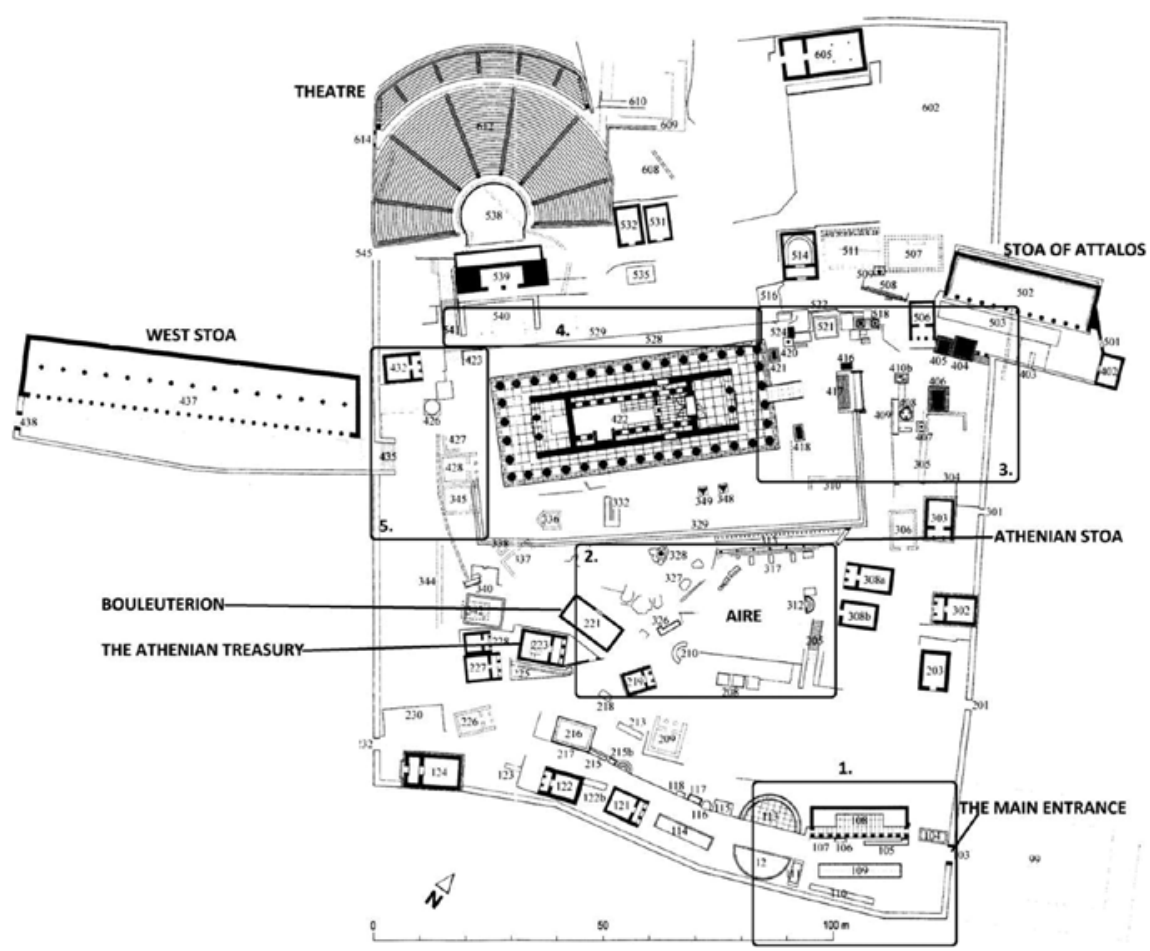

MAP 10 Map of the sanctuary of Delphi with division into particular regions: 1) The beginning of the Sacred Way; 2) The region between the Athenian Treasury and the Athenian stoa; 3) The east side of the Temple; 4) The northern regions; 5) The west Terrace.

Note: After Guide 2015, Planche v with modifications and adjustments made by the author. See Grzesik 2018a, 23-42.

after the battle of Marathon. ${ }^{67}$ The Athenian Marathon statue group is known only from Pausanias' report; there are no archaeological or epigraphic remains whatsoever. Moreover, some scholars argue that the group was a private dedication by Kimon rather than a collective Athenian monument. ${ }^{68}$

By the early fourth century вС $\mathrm{E}$, the Athenian statues near the main entrance were overshadowed by a series of later Spartan votive offerings: two rows of thirty-eight statues, preceded by Lysander's portrait ${ }^{69}$ and followed by images

67 Paus. 10.10.1-2. Bommelaer 1998, 538-542; Scott 2014, 293.

68 Duplouy 2006, 66-69; Keesling 2017, 103-140.

69 Paus. 10.9.7-12; Plu. Lys. 12 and 18; Plu. De Pyth. 8. Vatin 1991, 81-101. 


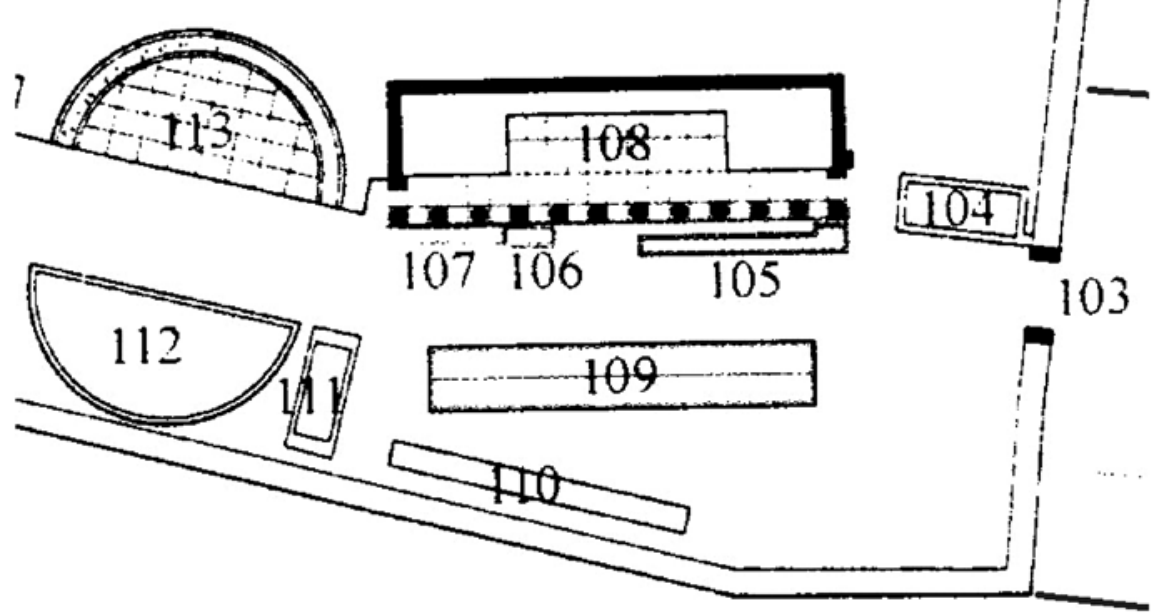

MAP 11 The beginning of the Sacred Way (no. 103 - the main entrance; no. 104 - the base of the Korkyrean bull; no. 105 - Arkadian heroes group; no. 106 - the base of Philopoemen (?); no. 107 - uncertain base; no. 108 - the Spartan stoa; no. 109 Spartan Aigopotamoi group; no. 110 - Marathon group with Miltiades statue; no. 111 - the base of the Argive horse; no. 112 - the base of the Seven and the Epigones; no. 113 - Argive heroes group)

Note: After Guide 2015, Planche v with modifications and adjustments made by the author.

of Lysander's allies from Aigospotamoi. ${ }^{70}$ The Spartan portraits in the front row were larger than life-size; as a consequence, Spartan monuments stolen from the Athenians occupied the prime place right after the main entrance. ${ }^{71}$ In other words, from $c .405 \mathrm{BCE}$ it was the Spartan statue gallery that the visitors saw after entering the sanctuary precinct. This, however, was not to remain so for long: in 369 вСЕ, the Arkadians commemorated their victory over the Lacedaemonians by dedicating an imposing statue that outshone the displays in the Spartan stoa (see Map 11). ${ }^{72}$

Additional contributions of the Athenians, the Spartans and the Arkadians, the greatest powers of classical Greece, led to the monumental congestion of the main entrance area by the late fourth century вСЕ. Powers of the later

70 Paus. 10.9.9-10.

71 See Arnold 1969 on the reconstruction of the Spartan row group, and Keesling (2017, 104108) for further interpretation.

$72 F d D$ 1.6. Scott 2014, 146. For more on spatial domination in Delphi in the fifth century вCE, see Scott 2010, 91-108. 


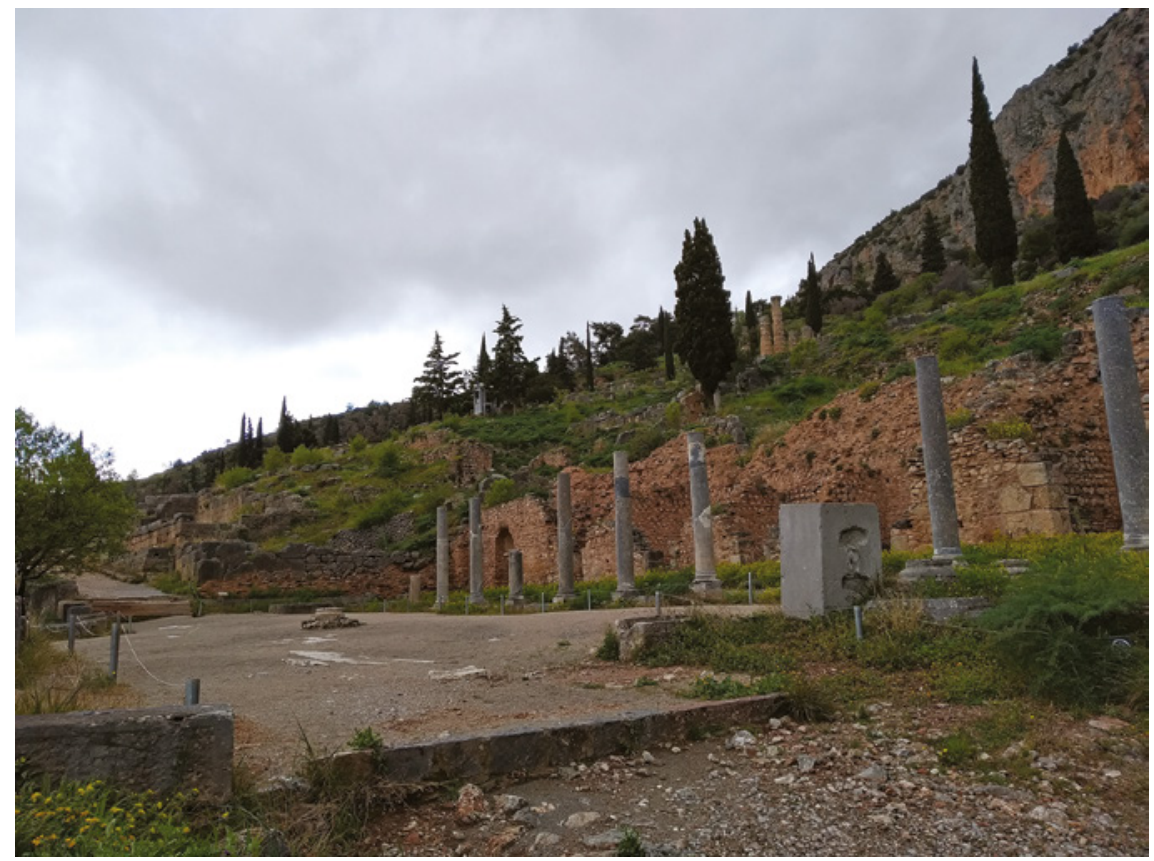

рното 4 The view on the main entrance and the Roman agora (Archaeological site of Delphi. The site is under the protection of the Ephorate of Antiquities of Phocis.) (C) THE HELLENIC MINISTRY OF CULTURE AND SPORTS/ ARCHAEOLOGICAL RESOURCES FUND

periods - the Aetolians, the Macedonians, the Attalids and the Romans - by necessity displayed their contributions in other regions of the Delphic temenos. Fittingly, archaeological excavations have unearthed only a handful of random Hellenistic and Roman statues in the main entrance area: by this time, the overuse of the entrance as a display space had led to its congestion and resultant loss of prestige, with honorands departing in search of other favourable presentation spaces further up the Sacred Way and closer to the temple. ${ }^{73}$

Another great statue gallery followed the Sacred Way from the Athenian Treasury and bouleuterion ${ }^{74}$ up to the Athenian stoa (Map 10, region no. 2). ${ }^{75}$ The Treasury of the Athenians has been the subject of numerous

73 For example, the statues of Theopompos of Knidos ( $F d D$ 1.527) and C. Lentulus, a Roman quaestor $(F d D$ 1.528).

74 On the uncertain location of the Delphic bouleuterion, see Guide 2015, 170-171.

75 Guide 2015, 175-177. For the reconstruction of the Athenian stoa in Delphi, see Jacquemin and Laroche 2014, 739-742. For stoai in Greece, see Dickenson 2017 a. 
studies, mostly because of a long-running controversy over the building's date. Pausanias states that the building was an offering after the battle of Marathon in 49 о в.${ }^{76}$ The strongly archaic style of the Treasury's sculptural decoration, however, has led many scholars to conclude that the monument has nothing to do with the Persian Wars and instead originates in the late sixth century BCE; the inscribed Marathon base must therefore be a later addition. ${ }^{77}$ Other scholars, by contrast, claim that the base and the Treasury are integral, and that the inscription names both structures asakrothinia (first-fruits) from the spoils of Marathon. ${ }^{78}$ In 1989, new excavations were undertaken to ascertain the relation of the Treasury to the base. The results of this work are summarised by P. Amandry who claims that Pausanias was right; the plan of the Treasury takes the base into account from the earliest phase of construction and thus both structures must date after the battle of Marathon. ${ }^{79}$

The hilly sector with the Athenian Treasury owed its desirability to its physical prominence (making locally erected statues tower conspicuously over monuments in other sectors) and the prestige of monuments placed along the polygonal wall, such as the renowned Sibyl rock and the Sphinx of Naxos. A superb piece of architectural ingenuity, the aforementioned Treasury of the Athenians exhibited proxeny decrees granted to the Athenians over the centuries, ${ }^{80}$ while the open area between the Treasury and the Athenian portico (called the aire), made space for many of Delphi's festivals and ritual processions. ${ }^{81}$ Over time, the spacious lot around the aire filled up with honorific monuments and sprawling exedras. The most prominent exedra in the area belonged to Herodes Atticus and his family: the Delphic polis honoured this great benefactor of Greece along with his wife and son, ${ }^{82}$ while the honorand in turn dedicated portraits representing his wife and offspring, which probably stood in the family exedra. ${ }^{83}$ As an excellent showground, the aire contained a bewildering variety of other honorific monuments. To name but a few personages honoured there, the aire housed images of (a) Ptolemaios II and Arsinoe; ${ }^{84}$

\footnotetext{
$76 \quad$ Paus. 10.11 .

77 Harrison 1965; Tölle-Kastenbe 1983, 573-584; Scott 2014, 112-113.

78 Audiat 1930, 296-321.

79 Amandry 1998, 75-9o. Consult also Neer 2004, 65-67.

8o Partida 2000, 48-70; Guide 2015, 151-166.

81 De La Coste-Messelière 1963, 734-736; Guide 2015, 173-175.

$82 \quad F d D_{3.66,} F d D_{3.71}$ and $F d D_{3.74}$.

$83 F d D$ 3.67-3.73. Appia Regilla, the wife of Atticus, dedicated one statue in Delphi; see FdD 3.72. Cf. Choix 2012, nos. 256-264; Ameling 1983, nos. 103-110 and 176. For Atticus' statues and exedra in Olympia, see Bol 1984. On Atticus' monuments in Athens, see Tobin 1997.

$84 \quad$ BCH 64/65.1940/1.63,3 (third century вСЕ).
} 
(b) Marcus Claudius Marcellus, Delphi's much-honoured benefactor; ${ }^{85}$ (c)Titus Avidius Quietus, the proconsul of Achaia; ${ }^{86}$ and (d) an unknown Roman legatus, who was honoured with a statue base found near the Sibyl rock. ${ }^{87}$ Notably, conspicuous Athenian monuments adorning the aire in the fifth century BCE eventually gave way to more prominent portraits of Hellenistic monarchs and high-ranking Roman officials, testifying to the enduing prestige attached to this display space. ${ }^{88}$

In 2014, Jacquemin and Laroche revised the hypothesis, first entertained by Martin, that the aire might have been located elsewhere (probably more to the west to the sanctuary), while the area which was judged to be the aire in fact served as the city's agora. ${ }^{89}$ To prove this hypothesis, Jacquemin and Laroche took into account two factors; the first referred to the presence of a political space in the sanctuary, while the second concerned the capacity of this place to accommodate the meetings of the city's assembly. ${ }^{90}$ The area identified as a potential agora measures $700-800 \mathrm{~m}^{2}$, while at a rate of $0.4 \mathrm{om}^{2}$ per person, based on the theater tiers, the venue could accommodate around 700 people distributed around a central space in the role of an orchestra. These estimates vary depending on the successive developments of the area and the display of various monuments over time. The number of places, however, is consistent with the estimates of the number of citizens of Delphi in the early Hellenistic period. The location of other civic buildings within this area, including the bouleuterion, might support the idea that the space located between the Athenian Treasury and the Athenian portico acted as the city's agora at least up to the second century BСE, when, as Roux suggests, the meeting place of the assembly had moved to the theater built by Eumenes II around 16о вСЕ. ${ }^{91}$ Unfortunately, neither any inscription nor any literary testimony provides the information on the location of the agora in Delphi to support this conclusion.

Farther ahead, the east side of the temple housed one of the most famous dedications and honorific monuments that marked the most eminent spot at Delphi (Map 10, region no. 3). In contrast to the rather narrow and thus quickly overcrowded area near the main entrance, the area east to the temple served for several centuries as a great statue gallery, benefitting from its larger capacity

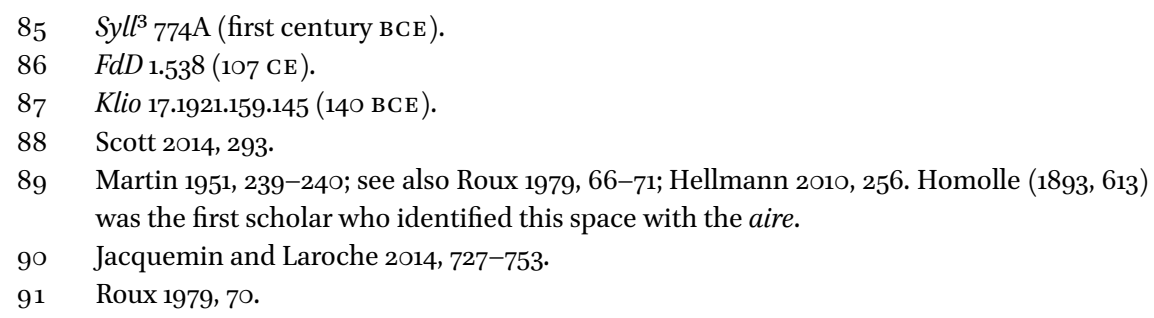




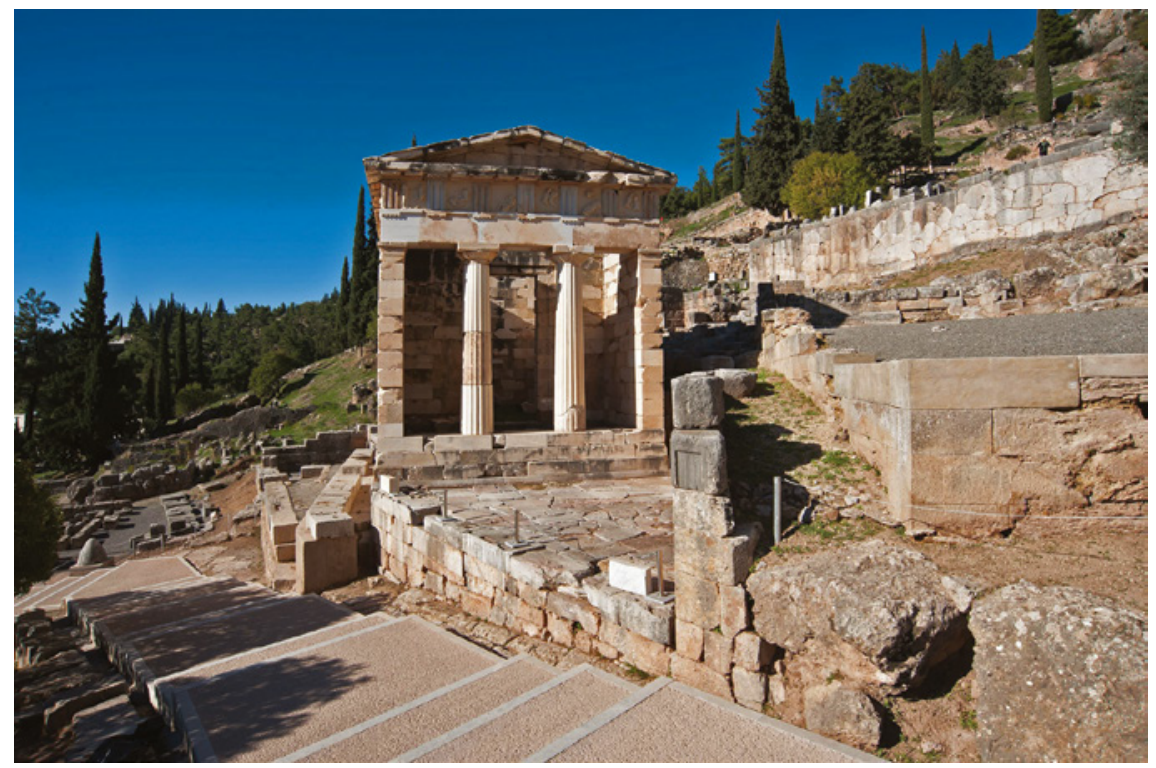

рното 5 The Athenian Treasury and the Sacred Way (Archaeological site of Delphi. The monument is under the protection of the Ephorate of Antiquities of Phocis.) (C) THE HELLENIC MINISTRY OF CULTURE AND SPORTS/ ARCHAEOLOGICAL RESOURCES FUND

and the later additions to its surface area. ${ }^{92}$ In the archaic and classical periods, the resplendent east temple terrace contained droves of divine statues and tripods in gold and silver; there stood the magnificent serpent column of Plataia, the Athenian palm tree dedication and spoils won from the Persians. ${ }^{93}$ By the Hellenistic period, the area exhibited statues of eminent officials, their bases left behind as material evidence. ${ }^{94}$ Monuments of illustrious Romans made their first appearance on the east terrace in 169 BCE, when Aemilius Paullus appropriated the base of Perseus' statue for his own image (Figure 15) ${ }^{95}$

92 The temple terrace was first discussed by Courby $1915^{-1927}$.

93 Scott 2010, 41-100 and App. A-C.

94 Extant are a portrait of Homer (Paus. 10.24.2), the gilden image of Gorgias (Paus. 10.18.7; Plin. $H N$ 33.83; Cic. Orat. 129. Poulsen 1920, 303), the statues of the Spartan king Archidamos, Philip II of Macedon, and the Epirotan princess Nereis ( $F d D$ 4.235).

$95 \quad F d D$ 4.36. Plb. 30.10.1-2. Krumeich 2017, 240. The temple terrace came to resemble a Julio-Claudian family gallery, its eastern border boasting statue bases of Augustus' grandchildren ( $F d D$ 4.256 A and B; Syll ${ }^{3} 779 \mathrm{~A}$ and B; CID 4.132), a portrait of Drusilla ( $\left.F d D 4.257\right)$, and an image of Nero ( $F d D$ 4.258). See Jannoray 1936, 382; Wood 1995, 457-482; Choix 2012, nos. 214 and 215, 222. Among the statues of the later emperors, we find an image of Nerva 


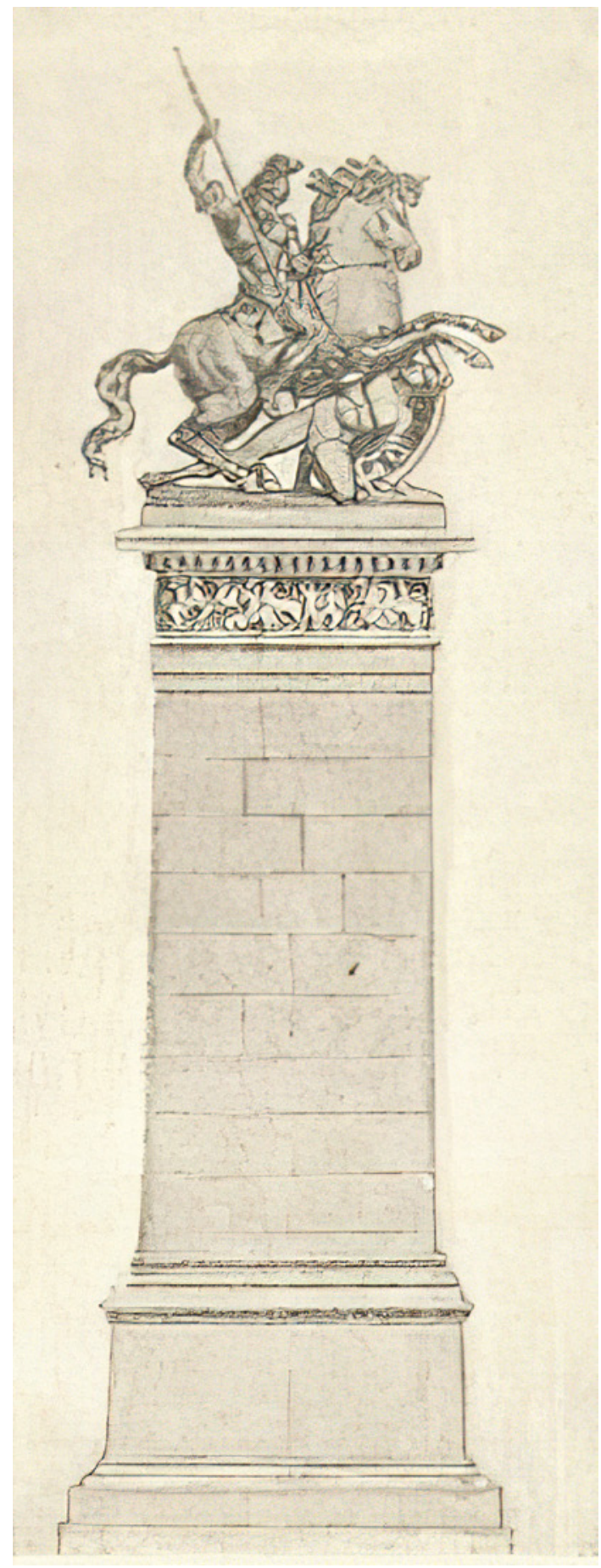

FIGURE 15

Reconstruction of the base of Aemilius Paullus

Note: After Michałowski 1949. 
Additionally, the area displayed a glut of imperial letters addressed to Delphians, which were engraved upon the orthostates built into the southern cella wall of the Apollo temple. ${ }^{96}$ Although spacious, the region east of the temple inevitably became brimming with statues by the early imperial period, such that Nero is said to have opportunistically freed some much-needed space when - according to Pausanias' account - he removed 500 impressive statues from the sanctuary. If, as I think is likely, stolen statues came primarily from the area east of the temple, then their removal would explain why this previously overburdened sector suddenly had enough space to house the portraits of emperors and prominent Roman officials who post-dated Nero, which were added long after other areas in the sanctuary reached the saturation point in the Hellenistic era. ${ }^{97}$

Although Krumeich mentions several epiphanestatoitopoi located at Delphi, the preserved honorific decrees leave no doubt that the east temple terrace was the most eminent and coveted display spot in the Delphic sanctuary. ${ }^{98}$ One key piece of evidence, the decree issued for Nikomedes III, the king of Bithynia,

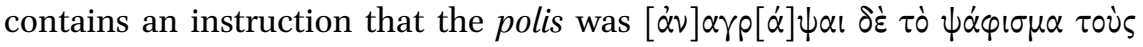

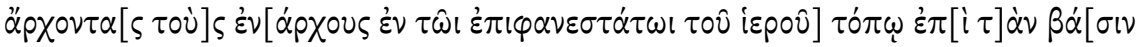

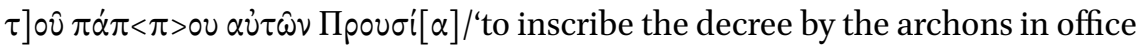
in the most eminent place in the sanctuary, on the base of the statue of his grandfather Prusias. 99 The monument of Prusias, onto which the inscription was carved, stood to the north east from the temple's entrance, next to the temple terrace. Another document of $c .104$ BCE also defines the eastern temple terrace as Delphi's most desirable honorific place. ${ }^{100}$ The text prescribes the most eminent setting for its display; as recommended, Aemilius Paullus' pillar which bears the inscription borders the south-eastern fringe of the temple's terrace. ${ }^{101}$

In direct contrast to southern and south-eastern districts of the Delphic sanctuary, which were already packed with honorific portraits and votive

set up by the Delphic polis ( $B C H$ 76.1952.627.2) and the so-called Emperor's monument that was believed to represent Domitian (Courby 1927, 277-281; Weir 2004, 153).

96 Weir 2004, 88.

97 Paus. 10.7.1.

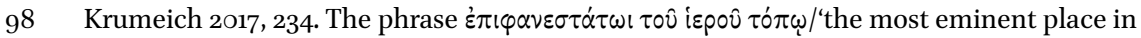
the sanctuary' is attested in six Delphic honorific decrees: $F d D$ 4.52 (c. 104 BCE), $F d D$ 3.384 (first century вСЕ), FdD 2.48 (97 BCE), FdD 4.77 (94 BCE); CID 4.13 (5О-1 ВCE); FdD 4.47 (98 CE). For the most prominent places, see Raeck 1995, 233; Bielfeldt 2012, 98-108; Ma 2013, 107-129 and $143^{-146 .}$

$99 \quad F d D 4.77$.

$100 \quad F d D 4.5^{2}$.

$101 \quad F d D$ 4.1. 


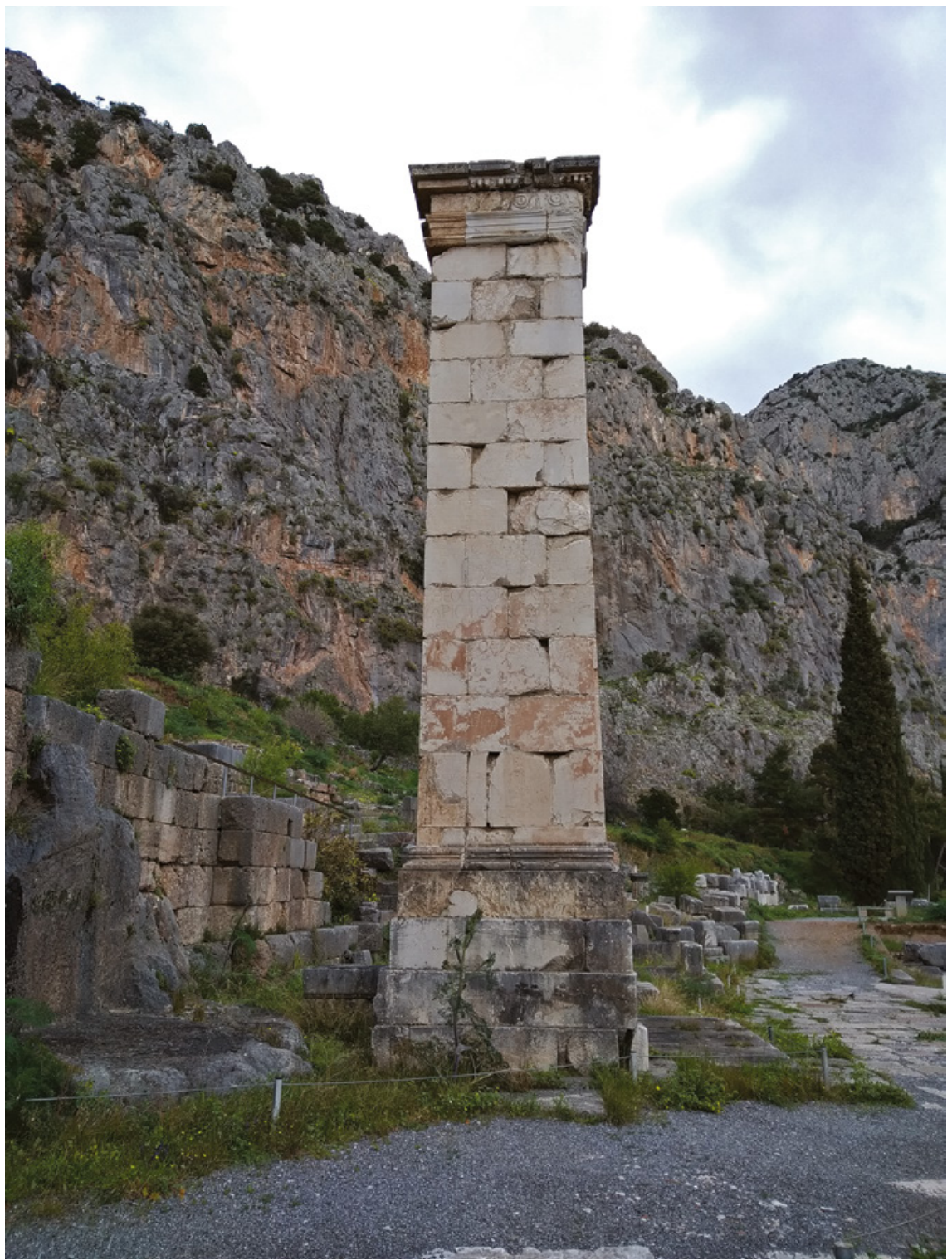

рното 6 Monument of Prusias II (Archaeological site of Delphi. The monument is under the protection of the Ephorate of Antiquities of Phocis.) (C) THE HELLENiC MiNistry of CULTURE AND SPORTS/ ARCHAEOLOGICAL RESOURCES FUND 
offerings by the classical period, the area to the north of the temple (Map 10, region no. 4) initially contained few statues. In the late fourth century вСЕ, this temple sector came under Macedonian control and received numerous monuments depicting their leaders. ${ }^{102}$ For example, Archon of Pella (the satrap of Babylonia) received a massive family base, which was dedicated to him by his compatriots. ${ }^{103}$ Nearby lay another Macedonian monument, the Krateros offering, possibly accompanying the famous dedication representing Krateros saving Alexander the Great's life during a lion hunt. Another family group statue belonged to a Macedonian commander named Alexandros and his wife. ${ }^{104}$ Finally, Daochos II of Pharsalos received the only surviving Delphic honorific monument made of marble. Born a Thessalian, Daochos II was nevertheless Philip II's close ally, dedicating his family monument in Delphi soon after the battle of Chaironeia. ${ }^{105}$ The Daochos group has received much scholarly attention for both its historical and artistic value. ${ }^{106}$ It is one of the best-preserved family portrait groups and represents eight adult men from six generations of a single Thessalian family. Keesling notices the political message that the Daochos monumet sent out: it promoted the memory of a Thessalian ruling family with close ties to Philip, but without the negative associations attached to the Thessalians in recent history, when the Aleuadai of Larisa promised Xerxes their help. ${ }^{107}$

The accumulation of Macedonian dedications and monuments north of the temple terrace demonstrates how the Macedonians laid claim to this less desirable - yet less crowded - north-facing lot, changing the Delphic statuary landscape. As the new military overlords of Greece, the Macedonians intended to flaunt their power in an increasingly overstimulating statuescape; accordingly, they turned to underutilised spaces north and west of the temple, strictly controlling their use to avoid overcrowding, which was endemic in the areas to the east and south of the temple. Selecting less congested regions for their dedications, the Macedonians began a new trend in monumentalisation of

102 For the monuments located in the northern area of the sanctuary, see De La CosteMesselière 1969, $73^{\circ}-75^{8}$. The first publication on the northern regions of the sanctuary is Pouilloux 196o.

$103 \quad$ BCH 83.1959.155-166 (the end of the fourth century вСЕ).

$104 F d D 4.464$ (315 BCE).

$105 F d D$ 4.46o.

106 Smith 1988, 25; Hintzen-Bohlen 1990, 134-137; Jacquemin and Laroche 1999 and 2001; Löhr 2000, $118-23$, no. 139. Geominy $(2007,84-98)$ redates the monument to $c .288-278$ вCE, although this has been rejected by other scholars; see Keesling 2017, 108-111.

107 Hdt. 7.6. 


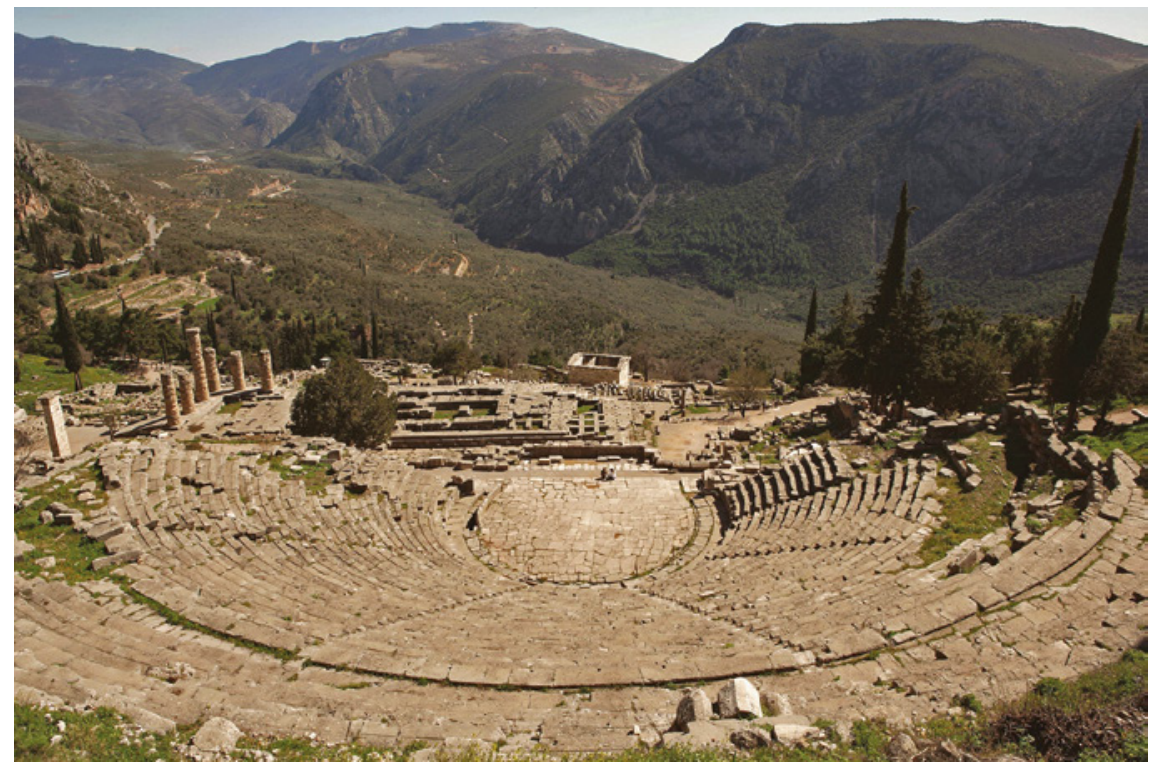

рното 7 The theatre and the view on the northern region of the temple of Apollo

(Archaeological site of Delphi. The monuments are under the protection of the Ephorate of Antiquities of Phocis.)

(C) THE HELLENIC MINISTRY OF CULTURE AND SPORTS/ ARCHAEOLOGICAL RESOURCES FUND

Delphi, a new strategy of spatial domination, that was later adopted and further developed by the Aetolians.

Honorific monuments and inscriptions accompanying them not only arranged space, but they also marked the prohibited areas within civic spaces. In Hellenistic Athens, there was a prohibition on setting up statues next to the famous portraits of the Tyrannicides. ${ }^{108}$ In Delphi, a law that was preserved as an inscription ceded a monopoly on the space that surrounded newly-raised stoa to the Attalids.

In the period between 241-226 вСе, the Amphictyony gave the Attalid kings permission to break the eastern boundary wall of the Apollo sanctuary at the level of the temple terrace and to raise their own stoa there. The newly constructed portico abutted a terracing wall, setting aside a large courtyard space for honorific monuments, where pillars of Attalos I and Eumenes II were located. ${ }^{109}$ Permission to erect new stoa was accompanied by a law which stressed that, 'no other dedications were to be put within the Attalid stoa

108 Ma 2013, 113-118.

109 Roux 2000, 196-199; Guide 2015, 218 and 230-231. 
complex except those from the Attalids themselves.'110 This decree ceded to the Attalids - the great Delphic benefactors of the late Hellenistic period - the complete monopoly on the space contiguous to their extraordinary building, thus guaranteeing that the Attalid monument would never be overshadowed by other dedications. This pivotal decision not only monumentalised the Delphic space but also excluded a part of its territory from any other agents' claims. By breaking the wall and raising the new stoa, the Attalids increased the capacity of the east side and consequently transformed the entire Delphic landscape. By laying their claim on the sanctuary's central zone, the Attalids ensured excellent visibility for their monuments. Statues erected in the Attalid exclusion zone stand out among other dedications, which were removed from surrounding constructions and were thus extremely prominent in the overcrowded temple district.

As we have seen, different poleis adopted different strategies with regard to the management of limited honorific space in Delphi. In the classical period, the Athenians boasted of their power by erecting magnificent monuments all over the sanctuary area; ${ }^{111}$ the League of the Aetolians and the Macedonians sought for free space in the cluttered temenos and created their zones of influences in less significant areas to compete with the Athenians for prestige and visibility; lastly, the Attalids carved out an exclusive lot in Delphi's most eminent area through generous benefactions to the Amphictyony. All these strategies of expressing power in the Delphic epigraphic space took careful consideration of pre-existing constructions, that aimed to surpass their predecessors in the most tasteful and yet visible manner possible. In the Hellenistic period, the League of the Aetolians found itself able to impose its control over the foreign public land in a manner previously unheard of in Delphi; therefore, to discuss the Aetolian doings in Delphi deserves a separate section in this chapter.

\subsubsection{The Aetolian Zone at Delphi}

The Aetolians controlled Delphi more effectively than any other polis had ever done: they competed not only in the sanctuary but for the sanctuary itself. In this section, I will argue that their domination over the western regions of the temenos not only changed the Delphic landscape, but in fact turned into the spatial confrontation between the east and west sides of the temple. As I noted above, the Aetolian publishing habit in Delphi expressed and supported

110 CID 4.85. See Roux 1987, 139 for the text with comments. See also Scott 2014, 177 .

111 It is possible that in the fifth century BCE the Athenians dominated not only the sanctuary of Apollo but also Athena's sanctuary at Marmaria, see Scott 2010, 95 fn. 107. 
the Aetolian command over the sanctuary. To express their power, the League adopted the Delphic fashion of publishing state decrees and superscribed its documents upon the Delphic building walls instead of on their own monuments. Consequently, the task of unpacking the Aetolian statue habit in its major aspects will help us to consider the Aetolian supremacy over Delphi from an epigraphic-spatial perspective. ${ }^{112}$

At the beginning of the third century BСE, the western temple precinct (Map 10, no. 5) remained devoid of any significant structures. It is uncertain when the so-called west stoa was erected, with some classifying it as a third century BCE Aetolian construction and others categorising the stoa as a fourth century ВСЕ hoplotheque. ${ }^{113}$ One thing is clearer: the area surrounding the western Delphic portico came to symbolise the Aetolian influence over the Delphic land after the Aetolians protected Delphi from the Gaulish invasion force. After a century of Aetolian monumental activity, the western Delphic portico all but transformed into a private Aetolian statue gallery. After $279 \mathrm{BCE}$, the Aetolian League dedicated divine statues (personified Aetolia, Artemis, Athena and Apollo) near the western stoa, the image of Aetolia adjoining images of Eurydamos and other Aetolian generals under his command. ${ }^{114}$ These in turn abutted portraits of Aetolian allies and benefactors, including images of members of the Ptolemaic royal family ${ }^{115}$ and king Eumenes II. ${ }^{116}$ The desirable space around the League's illustrious monuments attracted private dedicators from Aetolia, and the sizable body of evidence suggested that these were statues set up by private individuals for their relatives. ${ }^{117}$ Most of them stood close to the western temple terrace, but they occasionally adorned the eastern temple terrace ${ }^{118}$ or the aire. ${ }^{119}$

The Aetolian monumentalisation of Delphi shows several striking parallels with the Athenian efforts at monopolising space within the Delphic temenos. Just as the west stoa held Gaulish spoils and Aetolian commemorative

112 For the Aetolian political domination at Delphi, see Flacelière 1937, 367; Champion 1995, 213-220; Scholten 2000, 30-95; Sánchez 2001, 306-309.

113 For the origin of the west stoa and the debate concerning its erection, see Perrier 2o11, $39-56$.

114 Paus. 10.15.2 and 10.18.7; 10.16.4-6. See Hintzen-Bohlen 1992, 63-67.

$115 F d D$ 4.233 I, II, III and FdD 4.234. See Hintzen-Bohlen 1990, 144-154; Criscuolo 2003, 311-333.

$116 \quad F d D$ 3.230.

$117 F d D 4.130$ with $F d D$ 4.131 show five statues set up by Aristaineta, daughter of Timolaos for her family. $F d D$ 4.165 together with $F d D$ 4.166a concern six family images, while $F d D$ 3.149 is a fragmentary family group statue of four (?) people. $\mathrm{BCH} 64 / 65.1940 / 1.65$.

$118 F d D 4.131$ (c. 250 вСЕ).

$119 F d D 3.149(250-200$ вСE). 
triumphal inscriptions, so the eastern terrace and the Athenian Treasury was a symbol of the victory of the Greeks over the Persians. ${ }^{120}$ The League dedicated images of Eurydamos and other Aetolian generals; ${ }^{121}$ the Athenians placed statues of Miltiades by the main entrance to the sanctuary. By raising honorific monuments celebrating the Aetolian triumph over the Gauls, the Aetolians consciously alluded to the old Greek custom of commemorating military victories over the barbaroi in Delphi.

The almost complete Aetolian annexation of the public space to the west of the Delphic temple, in contrast to its more prominent - and multi-ethnic eastern counterpart, allowed the Aetolians to demarcate their exclusive communal territory within the cosmopolitan Delphic temenos. The Aetolians' unwritten right to a separate parcel of land in the sanctuary allowed them to enhance the visual appeal of monuments raised there: working unimpeded by other dedications, they planned and constructed impressive rows of statues (which were much more conspicuous than an isolated portrait), setting aside space for further statues to fill in the gaps or add missing lines. ${ }^{122}$ The Aetolian involvement near the western portico began when the Delphic statuescape by and large reached the point of oversaturation. The initial section of the Sacred Way and the lot near the aire housed Athenian monuments; the east side of the temple terrace accommodated offerings and dedications from communities all around the Mediterranean; and, finally, the northern flank contained the Macedonian monuments, whereas the area west of the temple still remained devoid of any significant structures. It would not do to add to the already overcrowded spaces: a simpler and cheaper solution entailed erecting an ordinary statue in an emptier lot, where it could attract attention, instead of being overlooked in a glamorous, but overcrowded space.

According to my interpretation, the Aetolian monumental activity was intended to turn the western sanctuary sector into a visitor magnet on a par with its opulent eastern counterpart. This drive led to the spatial confrontation between agents working in the eastern and western areas of the temple. The Aetolian efforts at enhancing the prestige of the western sector paid significant dividends: according to Scott, the western stoa in the third century вСЕ might have constituted a major (ceremonial?) thoroughfare between the sanctuary and the city, in contrast to its previous role of being a dead-ended annex to the sanctuary.123

\footnotetext{
120 Amandry 1978, 751-781; Knoepfler 2007, 1240; Neer 2004, 67.

121 Paus. 10.16.4 and 10. 15.2. See Knoepfler 2007, 1237-1240; Scott 2014, 171-172.

122 Jacquemin 1999, 158-161.

123 Scott 2014, 347 fn. 28; Perrier 2011, 48.
} 
The establishment of its own zone, a space with a space, allowed the Aetolians to broadcast a clear message of superiority among overcrowded, gaudy and often confusing displays of statues and inscriptions. Imposing monuments spoke more loudly about the Aetolian power than their political actions, such as seizing control over Delphic agonothetai, epimeletai, or even the Amphictyonic council itself. The Delphic sanctuary, a Panhellenic locus of honorific culture, also offered the Aetolians better opportunities for propaganda than their parochial shrine in Thermon. ${ }^{124}$ Monuments set up in famous sanctuaries embodied the wealth and renown of communities that funded them, serving as their cultural markers in foreign cultic territories. Delphi was not the only Greek site whose urban space was controlled by another city through carefully curated monumental displays. During the Athenian rule over Delos, new Athenian statues dominated the Delian monumental landscape. ${ }^{125}$ When the Achaean League seized Epidauros, they made the local sanctuary into the Achaean federal shrine which was a repository of documents and honorific statues. ${ }^{126}$ The Eretrians, the Samians and the Epidaurians respectively raised statues in the shrines of Artemis of Amarythos, Hera and Asklepios, while the Milesians adopted the shrine of Apollo at Didyma. ${ }^{127}$

\subsection{The Connection between Space and Power}

The discussion of this chapter has touched upon one of the central issues in the debates about the connection between power and space and the impact of honorific culture on local topographies. Thus far, the analysed material demonstrates that all regions of the Delphic temenos in the early Hellenistic period had already become congested with thousands of monuments, statues, treasuries and other constructions. Over time many of these were covered in inscriptions, as from the beginning of the third century вСе the Delphians preferred to superscribe honours on available building walls rather than raise free-standing stelai. The two centuries after Alexander the Great's death saw the largest increase in the number of inscriptions engraved upon the Delphic walls. Across the entire bedazzling sanctuary, countless decrees and gifts embodied and mapped Delphi's multidirectional social network. Evidently, an over-stimulated visitor would no longer linger over each and every inscription

\footnotetext{
124 For the Aetolian self-presentation in Thermon, see Grzesik 2018a, 23-42.

125 Herbin 2014a, 21-33.

126 Melfi 2013, 144 and 148-149.

127 Ma 2013, 8o-81 and 94-98.
} 
or statue, but instead focus on only the most prominent monuments, which in turn made benefactors compete with one another for visitors' attention, as the very aim of being granted an honour was to make its subject stand out as special. ${ }^{128}$ As a result, the race for visibility and monumentality began. The competition for limited display space has been already discussed above. As we noted there, to express their dominance the Athenians placed their monuments all over the temenos; the Attalids broke the boundary wall of the sanctuary and consequently increased the holding capacity of the most eminent honorific display space in Delphi; both the Macedonians and the Aetolians decided to avoid the overcrowded eastern terrace and erect their monuments to the north and west of the temple; and, similarly, the little-used Roman agora from the fourth century CE onwards became a premier showground for imperial statues. Nevertheless, even in this crowded landscape, the recipients of Delphic honours devised other strategies to enhance the prominence and visibility of their gifts, inviting the visitors' attention and making their honours stand out in the forest of portraiture in Delphi.

The first enhancement strategy was to set up a statue upon a high column. Krumeich noticed that Delphi had many more pillars and columns than (among others) Olympia. ${ }^{129}$ For example, Aristaineta in the mid-third century BCE dedicated family monuments on the east temple terrace and set them upon two Ionic columns, producing a striking display that towered over the local landscape. ${ }^{130}$ Any new addition to the congested eastern sector had to stand out through its grandeur and monumental form, as only the most majestic portraits were to be seen (and read).

Size and scale mattered in the race for visitors' attention: accordingly, another characteristic enhancement strategy was pursued in Delphi, namely portrait grouping. ${ }^{131}$ In the representative region no 1. (the entrance to the Delphic sanctuary), Sparta set up two rows of thirty-eight statues headed by Lysander's portrait, whose intention was to overshadow the monument dedicated to the Athenian eponymous heroes, that were also raised as a group statue. ${ }^{132}$ In the same region, the citizens of Argos and Arkadia erected a magnificent group of statues in the 36 os BCE. ${ }^{133}$ In the later periods, other regions of Delphic temenos often displayed statue groups, such as the family monuments of

\footnotetext{
128 Dillon and Baltes 2013, 238.

129 Krumeich 2017, 234.

$130 F d D$ 4.131. Ma 2013, 223-224. For a reconstruction, see Dillon 2010, 37 and 193.

131 Krumeich 2017, 234; Keesling 2017, 100-113.

132 Paus. 10.9.7-12; Plu. Lys. 12 and 18; Plu. De Pyth. 8. See Vatin 1991, 81-101.

133 Paus. 1.15.1 and 10.10.3-5. See Jacquemin 1999, nos. o66, o69.
} 
Daochos II, which were set up in the north-eastern region of the sanctuary, ${ }^{134}$ or portraits of Herodes Atticus and his relatives, which were located in the exedra by the aire. ${ }^{135}$ During the Aetolian domination in Delphi, the Epirotan princess Nereis dedicated a family group statue on the east temple terrace; $; 36$ similarly, the Amphictyony voted at least seven statues to the Chian hieromnamones, which were known to have originally stood near the Chian altar. ${ }^{137}$

Another honour enhancement strategy was to exploit a neighbouring monument's prestige in order to add to one's own, with fame attracting fame in a magnet-like fashion. Statues representing renowned kings, emperors or warriors drew everyone's attention. ${ }^{138}$ Keeping in line with Ma's idea that 'statues attract statues', famous dedications attracted other dedications, which in turn attracted others, rather like pieces of metal that, by clinging to a magnet, become magnetised themselves. ${ }^{139} \mathrm{~A}$ fitting example discussed above concerns the statue of Eumenes II and the proxeny decrees superscribed upon its base. ${ }^{140}$ Inscriptions carved on prominent monuments possessed a greater chances of being read by visitors than those written on less significant constructions, since the allure of primary dedications radiated towards and was in turn reflected by secondary inscriptions clustered around them. Elsewhere I have argued that a proximity to other famous statues, whether of deities, personifications or mortals, elevated the surrounding honorific statues and imbued them with a special significance which they did not possess on their own. ${ }^{141}$ The phenomenon of enhancing desirable space also comes to the foreground in the case of monuments placed on the eastern Delphic temple terrace, which was reserved for honouring truly outstanding personages. The prestige of this site derived not only from its proximity to the temple (primary prestige) but also from numerous statues that were already housed there (secondary prestige). Dedications adjacent to the eastern temple terrace were initially raised to take advantage of the temple's prestige, but they eventually produced their own measure of prestige (both via their inherent worth and the allure of the location) and in turn improved the desirability of the surrounding space. An excellent example concerns a fourth-century BCE statue of Phryne, that is mentioned by both

\footnotetext{
$134 F d D$ 4.46o. See Hintzen-Bohlen 1990, 134-137; Geominy 2007, 84-98.

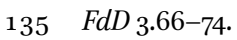

$136 \quad F d D$ 4.235.

137 CID 4.86-91; CID 4.102.

138 Ma 2013, 118-121.

139 Ma 2007, 89. For this phenomenon in Thasos, see Biard 2014, 57-68.

140 See above.

141 Grzesik 2018a, 32-33. See also Fejfer 2008, 51-52.
} 
Pausanias and Plutarch. ${ }^{142}$ Phryne, a famed courtesan, wielded enough influence to set up her own portrait on the prestigious Delphic east temple terrace, adjacent to images of kings and princesses. Located anywhere else, Phryne's statue would most probably have fallen into obscurity or have become a minor curiosity; however, surrounded by statues of Apollo and famous monarchs, it became the cynosure of all eyes. Similar tendencies developed in Athens and Olympia, when images of prominent people directed their viewers' attention to less significant portraits situated in their vicinity. ${ }^{143}$

Perhaps the most significant strategy for enhancing visibility introduced in the race for monumentalisation involved the construction of stoai. Although stoai are attested in classical Athens, Argos, Eretria and Sparta, only after the mid-third century BCE did they become the primary architectural medium for the Hellenistic monarchs to express their piety, generosity and power. ${ }^{144}$ In Greece, stoai frequently neighboured agorai; in Delphi, however, no less than four stoai abutted the temenos instead: (1) the Athenian portico - the oldest stoa in Delphi; ${ }^{145}$ 2) the Spartan stoa, situated by the main entrance to the sanctuary; 3) the portico west of Apollo's shrine; ${ }^{146}$ and 4) the Attalid stoa. ${ }^{147}$ Unsurprisingly, all these stoai in Delphi were funded by agents who competed for influence and control over Greece. In terms of the race to monumentalisation, no other constructions except the main temple of Apollo were grander than these spectacular buildings. The architectural sumptuousness of the western Delphic stoa suggests that it could have indeed been an Aetolian construction: not only does the building resemble other Aetolian propaganda projects in Delphi, but its construction also imitates the manner in which the Athenians controlled the Delphic public space, with the Athenian portico serving as a vital contribution to the Athenian building programme in classical Delphi. As a comparandum, spacious stoai dominated the landscape of Hellenistic Delos, which boasted that it possessed more stoai than any other large regional sanctuary in the Greek world. ${ }^{148}$

The above-mentioned strategies imprinted visible marks on the Delphic topography. Throughout the period of nearly nine centuries, the Delphic public space was divided, rearranged, overbuilt and razed in renewed attempts at

\footnotetext{
142 Paus. 10.15.1; Plu. De Pyth. 15.

143 Gómez Rieser and Perrin-Saminadayar 2017, 36.

144 For stoai in Greece, see Dickenson 2013, 37-75 and 2016.

145 Guide 2015, 175-177.

146 Perrier 2011, 39-56.

147 The Attalids excelled all other Hellenistic monarchs in their enthusiasm for stoa construction. See Dickenson 2013, 58 .

148 Griesbach 2010, 5; Dickenson 2013, 6o-63; Constantakopoulou 2017, 108-109.
} 
symbolically subjugating the Delphic display space. By the end of the third century вСЕ, any cultural monopolies on the Delphic space broke: the Athenians and the Spartans were only two of many agents vying for a slice of Delphi's grounds for presentation. ${ }^{149}$ So far, my analysis has focused on foreigners who raised monuments to negotiate and reaffirm their status in Delphi, but the local citizenry also made significant contributions to the Delphic statuescape. For example, the advent of Delphi's independence in 19 о вСE, after more than a century of Aetolian rule, enabled the Delphians to reassert their hold over their public space. The shedding of the Aetolian yoke fuelled the development of the local statuary habit, which was reflected in a significant rise in numbers of civic benefactions and portraits awarded by the Delphic polis. ${ }^{150} \mathrm{~A}$ similar process of local monumentalisation took place on Delos after $314 \mathrm{BCE} ;^{151}$ Delos' regaining of independence empowered the island's citizens to remodel the topography of the Delian sanctuary with an eye for stressing their newlywon freedoms. Also in the imperial period, Delphi experienced rampant oligarchisation and the rapid swelling of the ranks of its elites; a new aristocracy of Delphi sought to legitimise its status and foster a civic identity, with public monumental displays one of their many means to do so. ${ }^{152}$

\subsection{Conclusion}

Both local and foreign erectors of the monuments intended to shape what and who would be remembered by future generations. Changes in the local honorific habit and the constant evolution of the monumental landscape sent various messages which their dedicators meant to convey. The battle for the ever-shrinking public display space in the Delphic sanctuary necessitated that new constructions would attract viewers' attentions, stay in their memories, and overshadow previous dedications by rival powers. What really mattered was the proper location and configuration with other monuments and texts in a way that enhanced use of the available space. Statue bases, grand pillars, and the walls on which inscriptions were carved had fronts and backs and a preferred orientation, and so did the documents inscribed upon their several flanks. ${ }^{153}$ In this way the location of documents must have encouraged viewers

\footnotetext{
149 Biard 2017, 61-69.

15 O Grzesik 2019, 210-212.

151 Constantakopoulou 2017, 101.

152 Grzesik 2019, 200-227.

153 Ma 2013.
} 
and readers to perform certain actions, such as standing still, lingering, walking on and around, so that the 'access route', far from being a mere physical space, would have carried a semantic weight in its own right. This introduced movement into the static landscape, giving the power to the space. Now, the sanctuary consisted of lesser and greater foci of attention, with visitors wandering from one point of interest to another; the honorific landscape around them, imbued with agency, subtly and not so subtly nudged them from one propaganda piece to the next.

My aims in this chapter were to discuss how the location of honorific monuments and the accompanying inscriptions shaped the available display space and how rivalling political powers shaped and imprinted themselves upon it. My material sample, which encompasses over 700 years of the Delphic honorific habit, vividly demonstrates how monumental offerings, statues, and, most importantly, superscribed engravings organised and reshaped the urban space. Foreign agents and the local citizenry alike vied for the limited space at the Delphic Panhellenic sanctuary to showcase their greatness to the visiting crowds, with the Delphic materials reflecting and commenting on political tensions at both the international and local levels. The samples from Delphi and other sanctuaries which had wider regional appeal indicate that such communities used similar strategies for their management of public space. Delos, Delphi and other shrines served to house dedications extolling power, piety and generosity of Mediterranean individuals and societies. The powers of classical and Hellenistic Greece and the Romans used the Delphic space to define and position themselves within a complex nexus of power, their medium being sanctuary lots and their tools being new dedications. ${ }^{154}$

154 Constantakopoulou 2017, 104. 